\title{
B Lymphocyte Binding to E- and P-Selectins Is Mediated through the De Novo Expression of Carbohydrates on In Vitro and In Vivo Activated Human B Cells
}

\author{
Antonio A. Postigo, * Monica Marazuela, ${ }^{\star}$ Francisco Sánchez-Madrid, * and Manuel O. de Landázuri * \\ * Servicios de Inmunología and ${ }^{\ddagger}$ Endocrinología Hospital de la Princesa, Universidad Autonoma de Madrid, 28006 Madrid, Spain
}

\begin{abstract}
Cell adhesion to endothelium regulates the trafficking and recruitment of leukocytes towards lymphoid organs and sites of inflammation. This phenomenon is mediated by the expression of a number of adhesion molecules on both the endothelium and circulating cells. Activation of endothelial cells (EC) with different stimuli induces the expression of several adhesion molecules ( $E$ - and P-selectins, ICAM-1, VCAM-1), involved in their interaction with circulating cells. In this report, we have studied the binding of nonactivated and activated $B$ cells to purified $E$ - and P-selectins. Activated but not resting $B$ cells were able to interact with both selectins. This binding capacity of activated $B$ cells paralleled the induction of different carbohydrate epitopes (Lewis $^{\mathrm{x}}$, sialyl-Lewis ${ }^{\mathrm{x}}$, CD57 and CDw65) as well as other molecules bearing these or related epitopes in myeloid cells ( $L$-selectin, $\alpha \mathrm{L} \beta 2$ and $\alpha \times$ X2 integrins, and CD35) involved in the interaction of different cell types with selectins. B cells infiltrating inflamed tissues like in Hashimoto's thyroiditis, also expressed these selectin-binding carbohydrates in parallel with the expression of E-selectin by surrounding follicular dendritic cells. Moreover, the crosslinking of these selectin-binding epitopes resulted in an increased binding of $B$ cells to different integrin ligands. Thus, in addition to the involvement of integrins, $\mathbf{E}$ - and P-selectins could play an important role in the interaction of $B$ lymphocytes with the endothelium during $B$ cell extravasation into lymphoid tissues and inflammatory foci as well as in their organization into lymphoid organs. (J. Clin. Invest. 1994. 94:1585-1596.) Key words: B lymphocytes • selectins • integrins • carbohydrates $\cdot$ selectin-mediated signaling
\end{abstract}

\section{Introduction}

Leukocyte interaction with the endothelium is a critical step in inflammatory and immune responses that is mediated by differ-

\footnotetext{
Address correspondence to Dr. Manuel O. de Landazuri, Servicio de Inmunologia, Hospital de la Princesa, Diego de Leon 62, 28006 Madrid, Spain.

Received for publication 16 February 1994 and in revised form 9 June 1994.
}

1. Abbreviations used in this paper: CLA, cutaneous lymphocyte antigen; EC, endothelial cell(s); ECM, extracellular matrix; FDC, follicular dendritic cell(s); FN38, 38-kD proteolytic fibronectin fragment; GC: germinal center(s); ICAM, intercellular adhesion molecule; Le ${ }^{\mathrm{a}}$, Lewis $^{\mathrm{a}} ;$ Le $^{\mathrm{x}}$, Lewis ${ }^{\mathrm{x}} ;$ sLe $^{\mathrm{a}}$, sialyl-Lewis ${ }^{\mathrm{a}} ;$ sLe $^{\mathrm{x}}$, sialyl-Lewis ${ }^{\mathrm{x}} ; \mathrm{VCAM}$, vascular cell adhesion molecule.

J. Clin. Invest.

(C) The American Society for Clinical Investigation, Inc.

$0021-9738 / 94 / 10 / 1585 / 12 \$ 2.00$

Volume 94, October 1994, 1585-1596 ent adhesion molecules on both leukocytes and endothelial cells $(E C)^{1}(1,2)$. Two major groups of adhesive ligands have been described on EC: members of the Ig superfamily (ICAM-1, ICAM-2, VCAM-1, MAdCAM-1) and selectins (E- and P-selectins). On the other hand, leukocytes express different integrins and carbohydrate determinants interacting with endothelial Ig members and selectins, respectively (1-5). Cell activation by different stimuli increases leukocyte binding to EC by acting on both sides: inducing the expression of ICAM-1, VCAM-1, and E- and P-selectins on EC and increasing the avidity of leukocyte integrins for their ligands (1-5). Adhesion of neutrophils to EC and migration into tissues involve, in subsequent steps, selectins and integrins (3-5). While the initial attachment is mediated by the interaction of selectins with different carbohydrate determinants, the tight binding involves protein-protein interactions between functional activated $\beta 2$ integrins on neutrophils and members of the Ig superfamily on activated EC (3-7).

The selectin family (CD62E, P, L), comprising the two vascular E- and P-selectins and the leukocyte L-selectin, has been involved in leukocyte migration to sites of inflammation and entry into lymphoid organs (8). All three selectins bind to a similar, but not identical, set of glycosylated determinants (8$10)$. Thus, L-, E- and P-selectins recognize terminally $\alpha(2,3)$ sialylated forms of $\alpha(1,3)$ and $\alpha(1,4)$ fucosylated lactosaminoglycans such as sialyl-Lewis ${ }^{x}\left(\mathrm{sLe}^{\mathrm{x}}, \mathrm{CD} 15 \mathrm{~s}\right)$ and sialylLewis $^{a}\left(\right.$ sLe $\left.^{a}\right)$, respectively $(11-20)$. These epitopes decorate a number of glycoproteins and glycolipids (e.g., the L-selectin $[21,22]$ and CD66 [23]). In addition, E-selectin binds to the glycosylated cutaneous lymphoid antigen (CLA, HECA-452 antigen) expressed by $\mathrm{T}$ cells with hallmarks of skin homing $(16,24,25)$, as well as to the CDw65 epitope present on surface expressed glycolipids on neutrophils $(26,27)$. On the other hand, P-selectin recognizes the nonsialylated Lewis ${ }^{x}\left(\operatorname{Le}^{x}\right.$, CD15) (28) and certain sulfated and polyanionic polysaccharides $(29,30)$. L-selectin also interacts with sulfated and phosphomannan polysaccharides (8).

Regarding lymphocyte interaction with E- and P-selectins, albeit at much lower levels than neutrophils, NK cells, certain minor $\mathrm{T}$ cell subsets and chronically activated $\mathrm{T}$ cells, as those infiltrating chronic inflammatory sites, also interact with both selectins $(31-39)$.

Early studies documented the existence of a different pattern of migration to lymphoid organs by $\mathrm{B}$ and $\mathrm{T}$ cells and that this pattern could be altered during cellular activation (40). To that effect, $B$ cell activation increases the expression of several integrins that mediate binding to EC ( $\alpha$ L $\beta 2$ [LFA-1], $\alpha 4 \beta 1$ [VLA-4], $\alpha 4 \beta 7$ and $\alpha \mathrm{X} \beta 2$ [gp150,95]) with a different pattern than in $\mathrm{T}$ cells $(41-44)$. To further understand the molecular mechanisms controlling $\mathrm{B}$ cell recirculation, we investigated the ability of B cells to recognize E- and P-selectins and characterized the carbohydrate determinants involved in these interactions. 


\section{Methods}

Patients. Surgical thyroid tissue was obtained from three patients diagnosed of Hashimoto's thyroiditis according to commonly accepted criteria. Patients underwent surgery because of large nodular goiter (two) or suspicion of neoplasia during parathyroidectomy (one). At the time of surgery two were euthyroid under thyroid hormone and one was hypothyroid.

$m A b s$. B1 mAb (anti-CD20) was purchased from Coulter Immunol. (Hialeah, FL) and DRC-1 from Dakopatts (Glostrup, Denmark). TS1/ $11, \mathrm{HC} 1 / 1$ and TS1/18 mAbs (mouse IgG1) recognize the $\alpha \mathrm{L}, \alpha \mathrm{X}$ and $\beta 2$ integrin subunits, respectively (42). TEA $3 / 9 \mathrm{mAb}$ was produced in our laboratory and recognizes E-selectin as will be described elsewhere. The following $\mathrm{mAbs}$ were obtained by the generous donations of different investigators: Anti-E-selectin BB1.1 mAb (mouse IgG1) (Dr. R. R. Lobb, Biogen Inc., Cambridge, MA); anti-P-selectin G1 and S12 mAbs (mouse IgG1) (Centocor Inc., Malvern, PA); anti-Le ${ }^{x}$ G7C5 and G9F9 (mouse IgM) (Dr. J. S. Thompson, University of Kentucky, Lexington, KY); PM81 (mouse IgM) (28) (Dr. E. Ball, Darmouth-Hitchcock Medical Center, Hanover, NH); and AHN1.1 (mouse IgM) (Dr. K. M. Skubitz, Univ. of Minnesota, Minneapolis, MN); mAbs; anti-sLe ${ }^{\times}$CSLEX-1 (mouse IgM) (Dr. P. I. Terasaki, University of California, Los Angeles, CA); mAb; anti-CLA HECA$452 \mathrm{mAb}$ (rat IgM) (45) (Dr. E. C. Butcher, Standford University, Palo Alto, CA); anti-Le a $1 \mathrm{H} 10$ mAb (mouse IgG1) (16) (Dr. E. L. Berg, Standford University, Palo Alto, CA); anti-CD35 To5 mAb (Dr. D. Y. Mason, John Radcliffe Hospital, Oxford, UK); anti-CDw65 VIM2 mAb (mouse IgM) (Dr. W. Knapp, University of Vienna, Austria); antiCD66 YTH 71.3 mAb (mouse IgG1) (Dr. H. Waldmann, Cambridge University, Cambridge, England); anti-L-selectin DREG-56 mAb (mouse IgG1) (22) (Dr. T. K. Kishimoto, Boehringer Ingelheim Pharm. Inc., Ridgfield, CT); anti-sulfatides Sulph I mAb (mouse IgG1) (Dr. P. Fredman, Göteborg University, Mölndal, Sweden); and anti-I antigen C6 mAb (mouse IgM) (Dr. B. A. Fenderson, Thomas Jefferson University, Philadelphia, PA). The anti-CD57 HNK-1 mAb (mouse IgM) was obtained from the American Type Culture Collection (ATCC, Rockville, MD). Different isotype-matched irrelevant mAbs, mouse IgG1 P3X63 mAb (ATCC), mouse IgM MOPC 104E mAb (Sigma Chemical Co., St. Louis, MO) and rat IgM 2B6 mAb (donated by Dr. J. M. Rojo, CIB-CSIC, Madrid, Spain) were used as negative controls.

Cells and cell cultures. Human tonsillar B cells were obtained as previously described (42) grown in RPMI 1640 medium (Bio-Whittaker, M.A., Bioproducts, Walkersville, MD) supplemented with $10 \%$ FCS (Biochrom-Seromed, Berlin, Germany), $2 \mathrm{mM}$ L-glutamine, 25 $\mathrm{mM}$ Hepes, $50 \mathrm{U} / \mathrm{ml}$ of penicillin, $50 \mu \mathrm{g} / \mathrm{ml}$ of streptomicin (BioWhittaker, M.A., Bioproducts) and $2.5 \mu \mathrm{g} / \mathrm{ml}$ of amphotericin B (Fungizone, E. R. Squibb \& Sons España, Barcelona, Spain). This medium will be referred hereafter as complete medium. B cells were activated for several days with PMA (Sigma Chemical Co.) in complete medium. In experiments with neuraminidase, activated $\mathrm{B}$ cells were incubated in complete medium at $2 \times 10^{6} \mathrm{cell} / \mathrm{ml}$ with $120 \mathrm{mU} / \mathrm{ml}$ for $1 \mathrm{~h}$ at $37^{\circ} \mathrm{C}$ with neuraminidase from Vibrio cholerae (Behringwerke AG, Marburg, Germany).

Established cell lines were all obtained from ATTC and grown in complete medium.

FACS analysis. Flow cytometry analysis were performed as described (42). Briefly, $0.75-1 \times 10^{5}$ cells, pretreated at $4^{\circ} \mathrm{C}$ for $20 \mathrm{~min}$ with human $\gamma$-globulin (Heuber ICN España, Barcelona, Spain), were incubated with $50 \mu \mathrm{l}$ of hybridoma culture supernatants (or equivalent amount of $10 \mu \mathrm{g} / \mathrm{ml}$ solutions of purified $\mathrm{mAbs}$ ) for $30 \mathrm{~min}$ at $4^{\circ} \mathrm{C}$. In the case of the rat IgM HECA-452 mAb an additional step was performed by using specific mouse IgG1 anti-rat IgM RTM-32 mAb (Sigma Chemical Co.). After washing with PBS, cells were stained with a goat antimouse Ig $\mathrm{F}(\mathrm{ab}){ }_{2}{ }_{2}$ fragment-FITC (1:20 dilution) (Dakopatts) or antimouse IgM-FITC (1:100 dilution) (Sigma Chemical Co.). Specie matched isotype mAbs were used as negative controls (see above).

In experiments of double staining with CSLEX-1 and HECA-452 $\mathrm{mAbs}$, cells were incubated in subsequent steps with MOPC 104E or
CSLEX-1 mAbs and anti-mouse IgM-FITC. Then, cells were incubated in successive steps with 2B6 or HECA-452 mAbs, RTM-32 mAb, biotinylated goat anti-mouse IgG serum (Amersham Int. pIc., Buckinghamshire, England, UK) and phycoerythrin-streptavidin (1:500 dilution) (Vector Labs. Inc., Burlingame, CA).

Green and red cell immunofluorescences were examined by flow cytometry using a FACScan (Becton Dickinson, Mountain View, CA) and analyzed with the LYSIS program (Becton Dickinson).

Western blot analysis. Tonsillar T cells, $2 \mathrm{~d}$ phorbol ester activated B cells and U937 cells were lysed in buffer lysis (1\% NP-40 [Sigma Chemical Co.], $150 \mathrm{mM} \mathrm{NaCl}, 20 \mathrm{mM}$ Tris $\mathrm{ClH}$, pH 7.4, $2 \mathrm{mM} \mathrm{CaCl}_{2}$, $2 \mathrm{mM} \mathrm{MgCl}, 1 \mathrm{mM}$ PMSF [Sigma Chem. Co.]) during $15 \mathrm{~min}$ at $4^{\circ} \mathrm{C}$. Cell lysates were centrifugated at $15,000 \mathrm{rpm}$ for $30 \mathrm{~min}$ at $4^{\circ} \mathrm{C}$ and precleared with protein A Sepharose 4-CLB (Pharmacia Fine Chemicals, Uppsala, Sweden ). Aliquots of these lysates were run in 9\% SDSPAGE gels under reducing conditions. Proteins were then transferred to a PVDF membrane (Immobilon, Millipore Corp., Bedford, MA) overnight in $10 \mathrm{mM}$ CAPS buffer (Sigma Chemical Co.) pH 11.0. After blocking nonspecific binding with $10 \%$ nonfat dry milk in TBS ( 150 $\mathrm{mM} \mathrm{NaCl}, 20 \mathrm{mM}$ Tris $\mathrm{ClH}, \mathrm{pH} 7.4$ ) at $22-37^{\circ} \mathrm{C}$ during 90 min, strips of the blot were incubated either with HECA $-452 \mathrm{mAb}$ or preimmune rat serum plus $2 \mathrm{~B} 6 \mathrm{mAb}$ for $1 \mathrm{~h}$ at room temperature. After two washes at room temperature for $10 \mathrm{~min}$ in TBS-0.1\% Tween 20 (Merck, Darmstadt, Germany), strips were incubated with anti-rat IgM RTM-32 mAb for $1 \mathrm{~h}$. Strips were washed again in TBS-0.1\% Tween 20, incubated for $1 \mathrm{~h}$ in 1:1,000 dilution of rabbit anti-mouse Ig coupled to peroxidase (Dakopatts) and washed again in TBS- $0.1 \%$ Tween 20 . Reactive proteins were detected by $\mathrm{ECL}^{\mathrm{TM}}$ system (Amersham International plc.) following manufacturer's instructions.

Cell adhesion assays. Purified P-selectin, obtained as described (19, 35), was the generous gift of Dr. R. P. McEver (University of Oklahoma, Oklahoma City, OK). Recombinant soluble forms of E-selectin and VCAM-1 were kindly provided by Dr. R. R. Lobb (Biogen Inc.) (39). A recombinant ICAM-1 protein was generously donated by Drs. H. Hedman and E. Lundgren (University of Umeä, Sweden). Type I collagen was purchased from Sigma Chemical Co. and BSA (fraction V) from Merck. Proteolytic fibronectin fragment FN38 was the kind gift of Dr. A. García-Pardo (CIB-CSIC, Madrid, Spain) (41). 96-well microtiter high binding EIA II-Linbro plates (Flow Labs Inc., McLean, VA) were coated overnight at $4^{\circ} \mathrm{C}$ with $50 \mu \mathrm{l}$ of E-selectin, ICAM-1, VCAM-1 FN38, or type I collagen dissolved at $10 \mu \mathrm{g} / \mathrm{ml}$ in $50 \mathrm{mM}$ of $\mathrm{CO}_{3} \mathrm{HNa}, \mathrm{pH} 9.2$, or with P-selectin dissolved at $10 \mu \mathrm{g} / \mathrm{ml}$ in $0.1 \mathrm{M}$ $\mathrm{NaCl}, 20 \mathrm{mM}$ MOPS, pH 7.5, 0.01\% Brijs-96 (Sigma Chemical Co.). Thereafter, plates were satured with RPMI-1640-1\% HSA for $2 \mathrm{~h}$ at $37^{\circ} \mathrm{C}$ and washed with RPMI 1640 . Activated tonsillar B cells were labeled with $5 \mu \mathrm{Ci} / \mathrm{ml}$ of $\left[{ }^{3} \mathrm{H}\right]$-dThd (New England Nuclear Research Products, Boston, MA) overnight before being added to wells. Established cell lines were labeled with $50 \mu \mathrm{Ci}$ of ${ }^{51} \mathrm{Cr} \times 10^{-6}$ cells (NEN Research Products). 1-1.5 $\times 10^{5}$ cells/well in $100 \mu \mathrm{l}$ were added to wells and after settling for $30 \mathrm{~min}$ at $4^{\circ} \mathrm{C}$, plates were warmed to $37^{\circ} \mathrm{C}$ for $20 \mathrm{~min}$ or $30 \mathrm{~min}$ at $22^{\circ} \mathrm{C}$. In inhibition assays, cells were incubated for $30 \mathrm{~min}$ at $4^{\circ} \mathrm{C}$ with saturating concentrations of mAbs and added to wells. In crosslinking experiments, cells were incubated at $4^{\circ} \mathrm{C}$ for 45 min with $5 \mu \mathrm{g} / \mathrm{ml}$ of purified mAbs or saturating concentrations of culture supernatant or ascites, washed twice and incubated with goat anti-mouse or anti-rat IgM (Sigma Chemical Co.) for $45 \mathrm{~min}$ at $4^{\circ} \mathrm{C}$ and additional $30 \mathrm{~min}$ at $37^{\circ} \mathrm{C}$. In all adhesion assays each condition was performed on duplicate. After incubation, plates were gently washed for three times. The percentage of cell adhesion was determined as previously described (44) both by visual quantification in an inverted microscope and by lysing cells and measuring counts in $\beta-\left(\left[{ }^{3} \mathrm{H}\right]-\mathrm{dThd}\right)$ or $\gamma\left({ }^{51} \mathrm{Cr}\right)$ counters (Wallac Oy, Turku, Finland).

RNA blot hybridization. Total RNA from tonsillar B lymphocytes, HL60, U937, A431, and HepG2 cells was obtained as previously described (44). Equal amounts of RNA (30 $\mu \mathrm{g} /$ lane) were loaded on formaldehyde-agarose gels, subjected to electrophoresis, and transferred to nylon-nitrocellulose filters (Nitran ${ }^{\mathrm{TM}}$, Scheiler \& Schuell, Dassel, Germany). Specific fragments from the $\mathrm{NH}_{2}$-terminal noncatalytic re- 


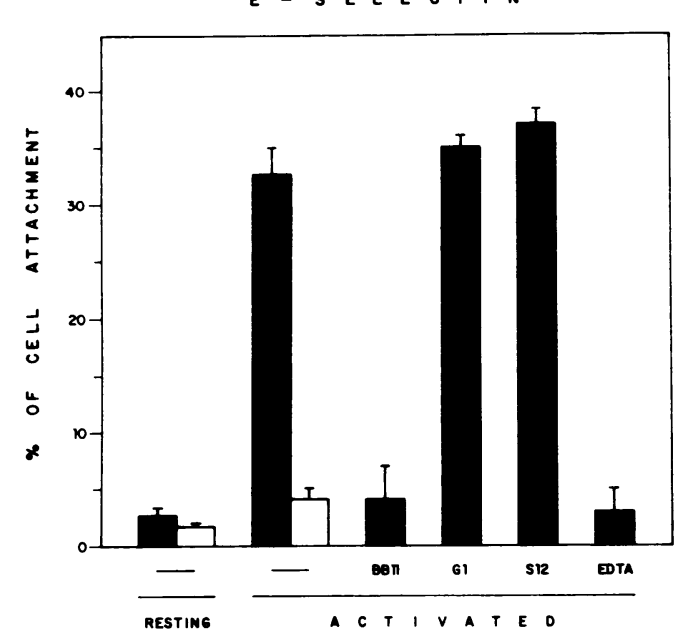

B

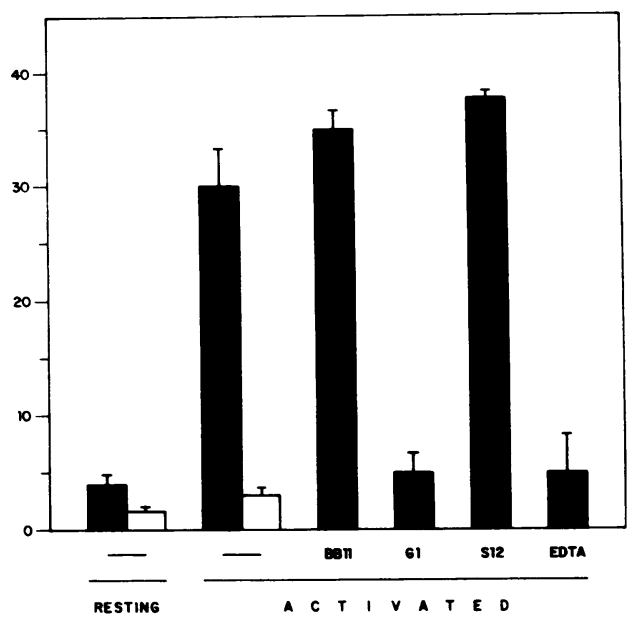

Figure 1. Adhesion of nonactivated and activated $B$ cells to $E-$ and $\mathrm{P}$-selectins. B cells either nonactivated or activated for $2 \mathrm{~d}$ with PMA $5 \mathrm{ng} / \mathrm{ml}$ were incubated with anti-E-selectin BB11 mAb, antiP-selectin G1 and S12 mAbs or 5 mM EDTA and assayed for binding to recombinant soluble $\mathrm{E}-(A)$ and P-selectins $(B)(\square)$ or type I collagen ( $\square$ ). Adhesion assays were performed as described in Methods. gion of fucosyltransferases (FucT) III, IV, V and VI were obtained by enzymatic digestion or PCR amplification on the corresponding cloned cDNA. The 153 bp FucT-III probe was obtained by PCR amplification (forward primer: 5' CGT GTG TCC CGA GAC GAT 3'; reverse primer: 5' CAT CTC TGA ACA GCG GG 3') on a FucT-III pCDM7 construct (kindly donated by Dr. J. B. Lowe, University of Michigan, Ann Arbor, MI) (46). The 512-bp FucT-IV probe was obtained by Eco 47 III restriction on the FucT-IV (ELFT) CDM8 construct (generously donated by Dr. S. Goelz, Biogen Inc., Cambridge, MA) (14). For hybridization with the FucT-V, a 189 bp PCR product amplified (forward: as for FucT-III; reverse: 5' CAT CTC TGA GCA GCG GG 3') on the FucT-V-pcDNAI construct (also kindly donated by Dr. J. B. Lowe) (47) was used. FucT-VI hybridization was performed by using a 147 bp PCR product amplified (forward: 5' CGT GTG TCT CAA GAC GAT 3'; reverse: as for FucT-V) on a FucT-VI-CDM8 construct (a gift of Drs. K. L. Koszdin and R. Bowen, CIBA-GEIGY, Summit, NJ) (48). These fragments were labeled with $\left[{ }^{32} \mathrm{P}\right]-\mathrm{dCTP}$ (NEN Research Products) and added to the mRNA-containing filters. At least two RNA gel were prepared, blotted and hybridized for each FucT. Blots were subjected to high strigency wash conditions.

Immunohistochemistry. Thyroid tissue specimens were obtained by surgical procedures, frozen in O.C.T. (Miles Laboratories, Elkhart, IN) and stored at $-80^{\circ} \mathrm{C}$. Single immunostainings were performed by an indirect immunoperoxidase method (41).

In double immunostaining, after the development of the DAB reaction, the sections were saturated with nonspecific mouse Ig, washed and then incubated with the second $\mathrm{mAb}$ in the same conditions. Subsequently, they were incubated with a rabbit anti-mouse IgG coupled to alkaline phosphatase (Dakopatts). Finally, the alkaline phosphatase reaction was developed by incubating the sections with a solution of $0.2 \mathrm{mg} / \mathrm{ml}$ of Naphtol AS-MX phosphate, $1 \mathrm{mg} / \mathrm{ml}$ of fast-blue salt and $10^{-5} \mathrm{M}$ Levamisole (all from Sigma Chemical Co) dissolved in $50 \mathrm{mM}$ Tris $\mathrm{ClH}, \mathrm{pH}$ 8.4. The reaction gives a bright blue precipitate that contrasts with the brown color of the DAB reaction. Each section was examined under scope by at least two different expert observers.

\section{Results}

Binding of activated $B$ lymphocytes to $E$ - and P-selectins. To study whether activated $B$ cells bind to endothelial members of the selectin family, we examined their attachment to recombinant E-selectin and purified P-selectin. Tonsillar B cells activated for two days with the phorbol ester PMA $(5 \mathrm{ng} / \mathrm{ml})$ attached to E- and P-selectins whereas nonactivated B cells did not (Fig. 1). B cell binding to E-selectin was specifically inhib- ited by anti-E-selectin BB11 mAb but not by anti-P-selectin G1 and S12 mAbs (Fig. $1 A$ ). Conversely, cell binding to Pselectin was selectively blocked by $\mathrm{G} 1 \mathrm{mAb}$ but not by BB 11 $\mathrm{mAb}$ and the nonblocking anti-P-selectin $\mathrm{S} 12 \mathrm{mAb}$ (Fig. $1 \mathrm{~B}$ ). $\mathrm{B}$ cell binding to $\mathrm{E}$ - and $\mathrm{P}$-selectins was also inhibited in the presence of $5 \mathrm{mM}$ EDTA (Fig. 1). No significant binding to type I collagen was observed in any activation state (Fig. 1).

$B$ cell activation induces the expression of carbohydrate determinants implicated in cell binding to selectins. The capacity of activated B cells to interact with both endothelial selectins, prompted us to explore the expression by $\mathrm{B}$ cells of the determinants responsible for such interactions. Cells recognize $E$ - and P-selectins through different carbohydrate epitopes (for reviews see references 8 and 10 ). Thus, while $\operatorname{Le}^{x}$ and $\operatorname{sLe}^{x}$ are expressed by the great majority of monocytes and neutrophils, $\mathrm{sLe}^{\mathrm{a}}$ has only been described on epithelial tumor cells. sLe ${ }^{\mathrm{x}}$ is also expressed by a small fraction $(\sim 5-15 \%)$ of circulating $\mathrm{T}$ lymphocytes $(24,49)$. Using a wide panel of mAbs, we studied the expression of these and related carbohydrate determinants on activated and nonactivated B cells (Fig. 2). Le ${ }^{x}$, sLe $^{x}$ and $\mathrm{sLe}^{\mathrm{a}}$ were barely expressed or absent on nonactivated $\mathrm{B}$ cells (Fig. 2). Activation with phorbol esters induced the expression of both $\operatorname{Le}^{\mathrm{x}}$ and $\mathrm{sLe}^{\mathrm{x}}$, but not $\mathrm{sLe}^{\mathrm{a}}$, that was evident by day 1 reaching the peak between 24 to $48 \mathrm{~h}$. Afterwards, some downregulation of these epitopes was observed (data not shown). B cell activation also increased the expression of $\alpha \mathrm{L} \beta 2$ and $\alpha \mathrm{X} \beta 2$ integrins, CD35 and L-selectin (Fig. 2). Interestingly, on neutrophils the $\mathrm{Le}^{\mathrm{x}}$ epitope decorates CD35 and $\beta 2$ integrins $(50)$, whereas the $\mathrm{sLe}^{\mathrm{x}}$ is modifying the L-selectin and CD66 antigens (21-23). However, CD66 expression was not detected on B cells in any activation state.

Some authors have reported that E-selectin, but not P-selectin, interacts with internally sialylated fucosylated polylactosamines, such as the myeloid CDw65 antigen $(26,27)$. B cell activation also led to an induced expression of CDw65, which was not detected on nonactivated B cells, as demonstrated by the reactivity with the anti-CDw65 VIM-2 mAb (Fig. 2).

P- and L-selectins, but not E-selectin, also recognize sulfated polyanionic glycans including different glycosphingolipids as those recognized by the anti-CD57 HNK-1 mAb (51). Again, nonactivated $\mathrm{B}$ cells were negative for these sulfated 

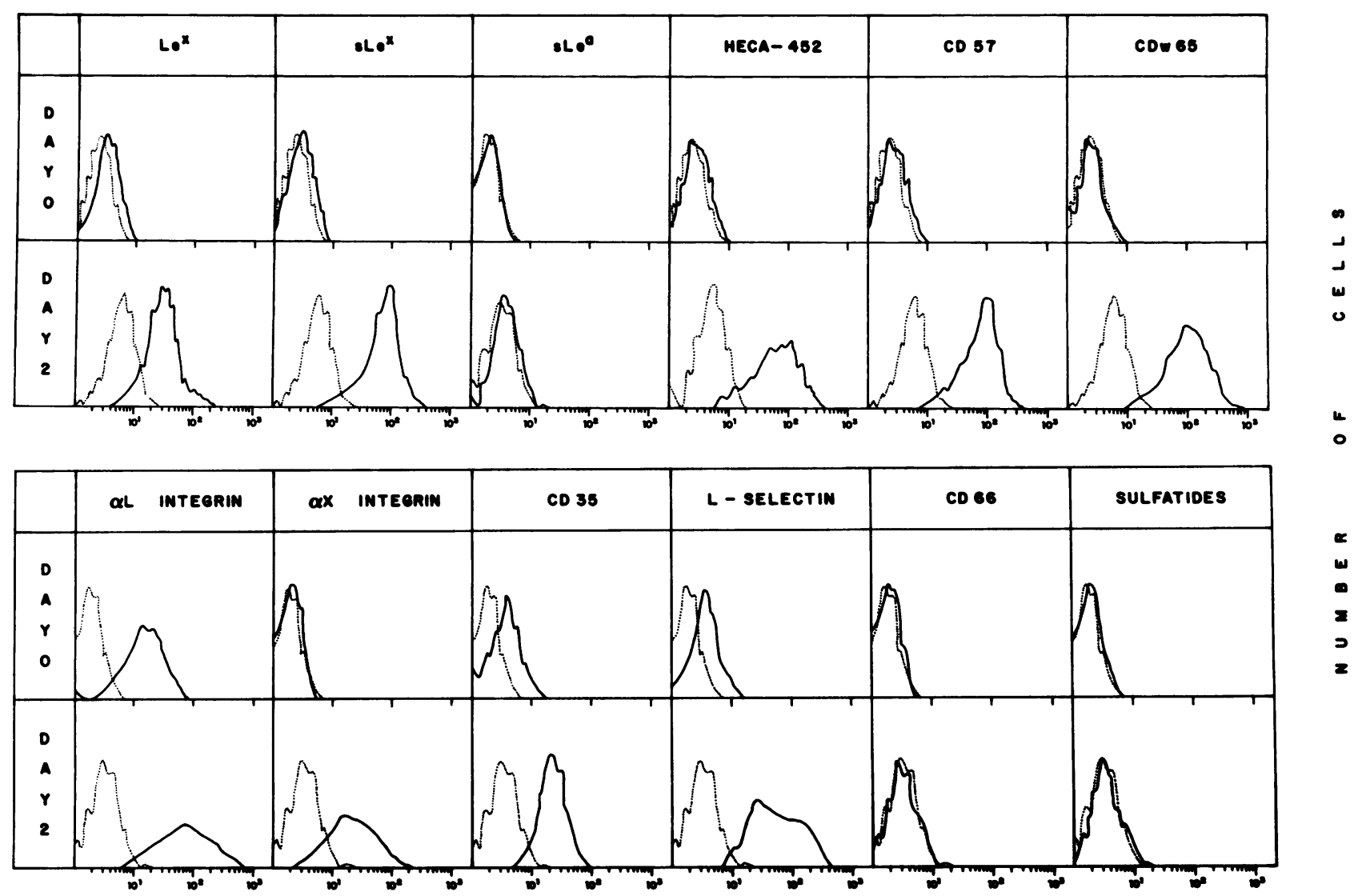

LOP FLUORESENGE INTENBITY

Figure 2. Expression of different carbohydrate epitopes on nonactivated and 2-d-activated B cells. Immunofluorescence flow cytometry analysis was performed on B lymphocytes either untreated or treated for $2 \mathrm{~d}$ in the presence of PMA $(5 \mathrm{ng} / \mathrm{ml})$. Cells were labeled with G7C5 mAb (Le $\left.{ }^{\mathrm{x}}\right)$, CSLEX-1 mAb (sLe $\left.{ }^{\mathrm{x}}\right), 1 \mathrm{H} 10 \mathrm{mAb}\left(\mathrm{sLe}^{\mathrm{a}}\right), \mathrm{HECA}-452 \mathrm{mAb}$ (sLe $\left.{ }^{\mathrm{x}} / \mathrm{sLe}^{\mathrm{a}} / \mathrm{CLA}\right), \mathrm{HNK} 1 \mathrm{mAb}$ (CD57), VIM-2 mAb (CDw65), TS1/11 mAb ( $\alpha \mathrm{L}$ integrin), HC1/1 ( $\alpha$ X integrin), To5 mAb (CD35), Dreg-56 mAb (L-selectin), YTH 71.3 mAb (CD66), and Sulph I mAb (sulfatides) (solid lines). Irrelevant isotype matched MOPC-104E (mouse IgM), 2B6 (rat IgM) and P3X63 (mouse IgG1) mAbs were used as negative controls (dotted lines). Experiments were performed as described in Methods. $(x$-axis) log fluorescence intensity; $(y$-axis) frequency.

glucuronyl ceramides, whereas activation induced the expression of this epitope (Fig. 2). Although a good correlation between cell binding to P-selectin and reactivity with the Sulph I $\mathrm{mAb}$, recognizing sulfatides, has been established (29), we were unable to detect expression of this epitope on either nonactivated or activated B cells (Fig. 2).

Although nonactivated B cells were not stained with HECA$452 \mathrm{mAb}$, activated $\mathrm{B}$ cells showed strong reactivity for this $\mathrm{mAb}$ (Fig. 2). The HECA-452 mAb in addition to recognize CLA, also reacts with a common determinant on both $s L e^{x}$ and $\mathrm{sLe}^{\mathrm{a}}$ antigens which may represent the glycosylated epitope recognized by E-selectin on these saccharides (16). Therefore, we investigated whether $B$ cell reactivity with HECA-452 mAb was due to the recognition of the $s L e^{x}$ determinant or to the presence of the CLA antigen on B lymphocytes. Double labeling with HECA-452 and CSLEX-1 mAbs showed that the majority of activated $B$ cells react with both $\mathrm{mAbs}$ and, contrary to that observed in T lymphocytes $(24,52)$, no B cell subsets expressing distinctively any determinant could be distinguished (Fig. $3 A$ ). To ascertain whether HECA-452 reactivity was related with the expression of the 200-kD CLA glycoprotein(s) described on $T$ cells $(45,52)$, Western blot analyses were per- formed. As shown in Fig. $3 B$, HECA-452 mAb reacted on B cells with proteins at the level of $200 \mathrm{kD}$ similarly to that observed in tonsillar T cells (Fig. $3 B$ and reference 45). Additional bands ranging from 50 to $180 \mathrm{kD}$ were also observed, probably reflecting $\mathrm{sLe}^{\mathrm{x}}$ reactivity as described in other cell types (Fig. $3 B$ and reference 45 ). Bands $\sim 130 \mathrm{kD}$ were found in lysates from U937 cells (Fig. $3 B$ and reference 45 ).

Taken together, these results indicate that whereas most selectin-binding carbohydrates were virtually absent on nonactivated $B$ cells, $B$ cell activation induces the expression of $L^{x}$, sLe $^{\mathrm{x}}, \mathrm{CD} 57, \mathrm{CDw} 65$ and protein(s) with relative mobility of $200 \mathrm{kD}$ reacting with the HECA-452 mAb. The specificity in the recognition was underscored by the loss of reactivity of activated B cells with CSLEX-1, HECA-452, and VIM-2 mAbs upon treatment with neuraminidase (data not shown).

Carbohydrate determinants involved in $B$ cell binding to $E$ and $P$-selectins. To ascertain which carbohydrate epitopes from those induced upon activation were implicated in $\mathrm{B}$ cell binding to E- and P-selectins, adhesion assays to both selectins were performed in the presence of different mAbs (Figs. 4 and 5).

Binding of activated $B$ cells to E-selectin was unaffected by cell preincubation with anti-Le ${ }^{\mathrm{x}} \mathrm{PM} 81 \mathrm{mAb}$. By contrast, 


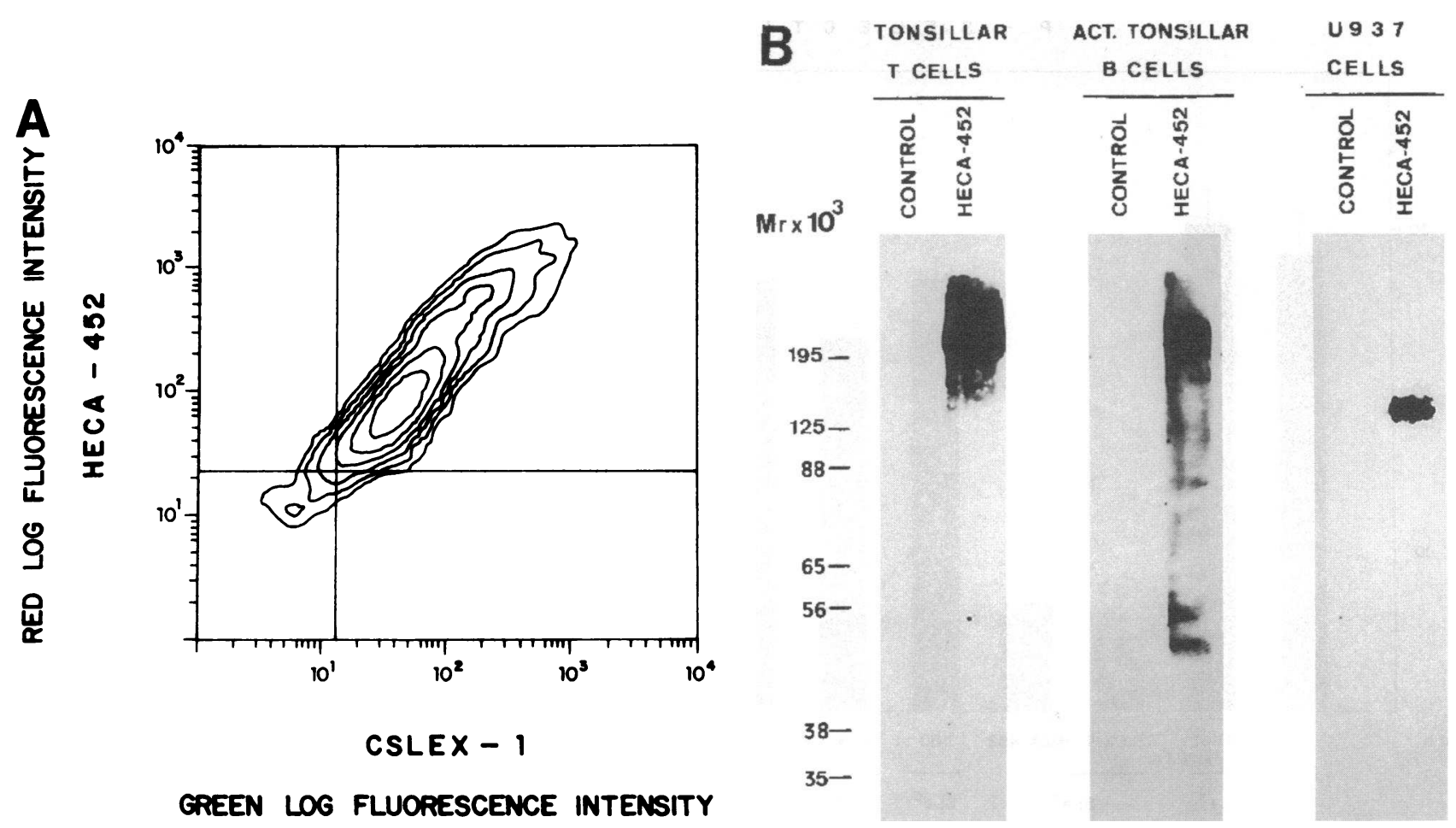

Figure 3. Expression of CLA by activated B cells. (A) Two-color immunofluorescence analysis with CSLEX-1 and HECA-452 mAbs on 2-dPMA-activated B cells. Experiments were performed as described in Methods. Division in quadrants was established on the basis of the fluorescence of the negative controls (not shown). (B) HECA-452 mAb reactivity on different cell types. Western blot strips of cell lysates from tonsillar $\mathrm{T}$ lymphocytes, 2-d-PMA-activated B cells, and U937 cells were incubated with HECA-452 mAb and a control rat IgM mAb. Relative mobility of prestained molecular weight markers is indicated $(1,000 \mathrm{kD})$. Western blot analysis was performed as described in Methods.

CSLEX-1 mAb, against the sialylated form of $\mathrm{Le}^{\mathrm{x}}$, inhibited $\mathrm{B}$ cell binding to E-selectin (Fig. 4). A similar blocking effect was found with the HECA-452 mAb. However, anti-sLe ${ }^{a} 1 \mathrm{H} 10$,
anti-CDw65 VIM-2 and anti-CD57 HNK-1 mAbs did not significantly affect B cell attachment to E-selectin (Fig. 4).

The binding of activated B lymphocytes to P-selectin was
E - S E L E C T I N

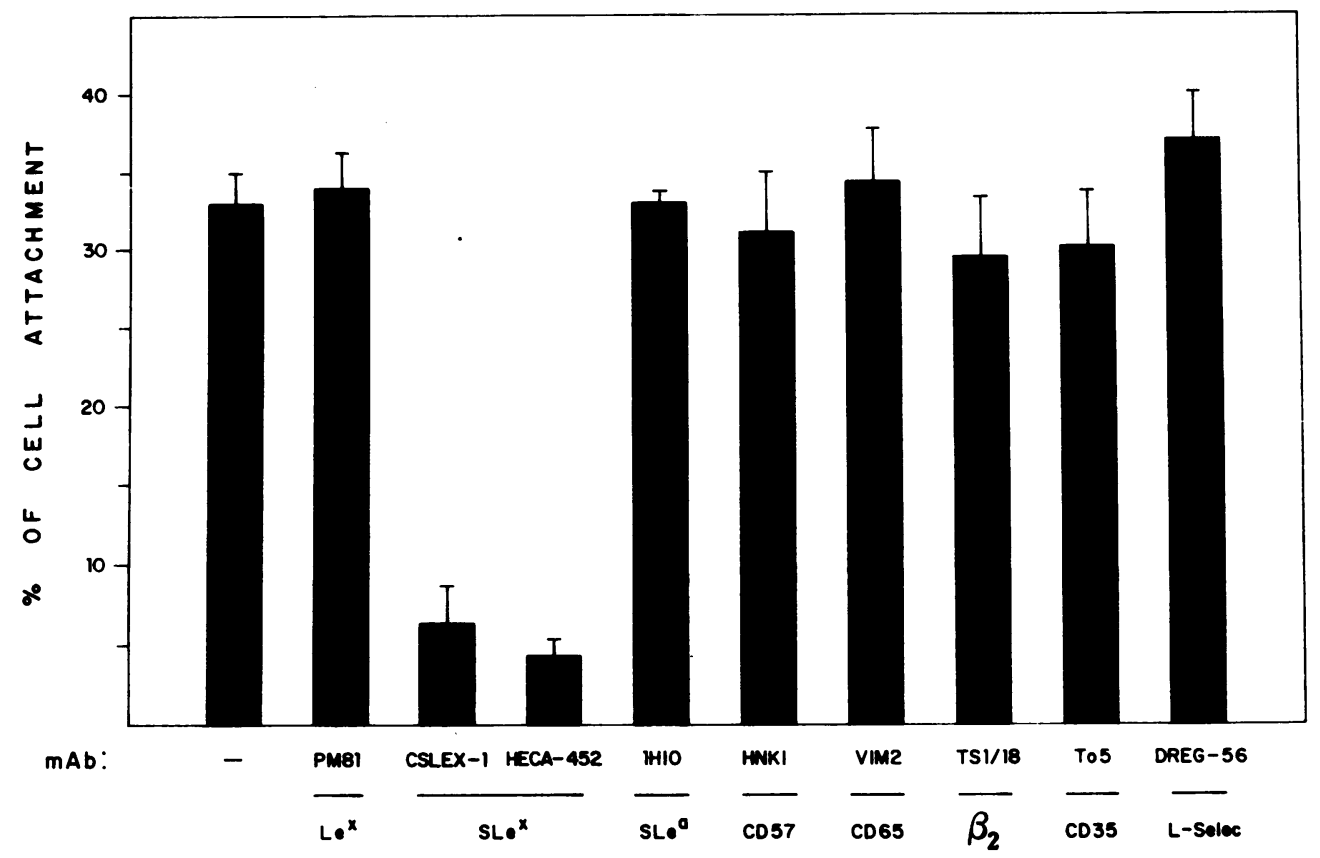

Figure 4. B cell binding to E-selectin in the presence of mAbs against different carbohydrate epitopes. B cells treated with PMA 5 $\mathrm{ng} / \mathrm{ml}$ for $2 \mathrm{~d}$ were incubated with mAbs against E-selectin (BB11 mAb), Le ${ }^{x}$ (G7C5 + PM81 $\mathrm{mAb}), \mathrm{sLe}^{\mathrm{x}}$ (CSLEX-1 mAb), $\mathrm{sLe}^{\mathrm{x}} / \mathrm{CLA}$ (HECA-452 mAb), CDw65 (VIM-2 mAb), CD57 (HNK-1 mAb), L-selectin (Dreg$56 \mathrm{mAb}$ ), CD35 (To5 mAb), $\beta 2$ integrin (TS1/18 mAb). Adhesion assays were performed as described in Methods. 


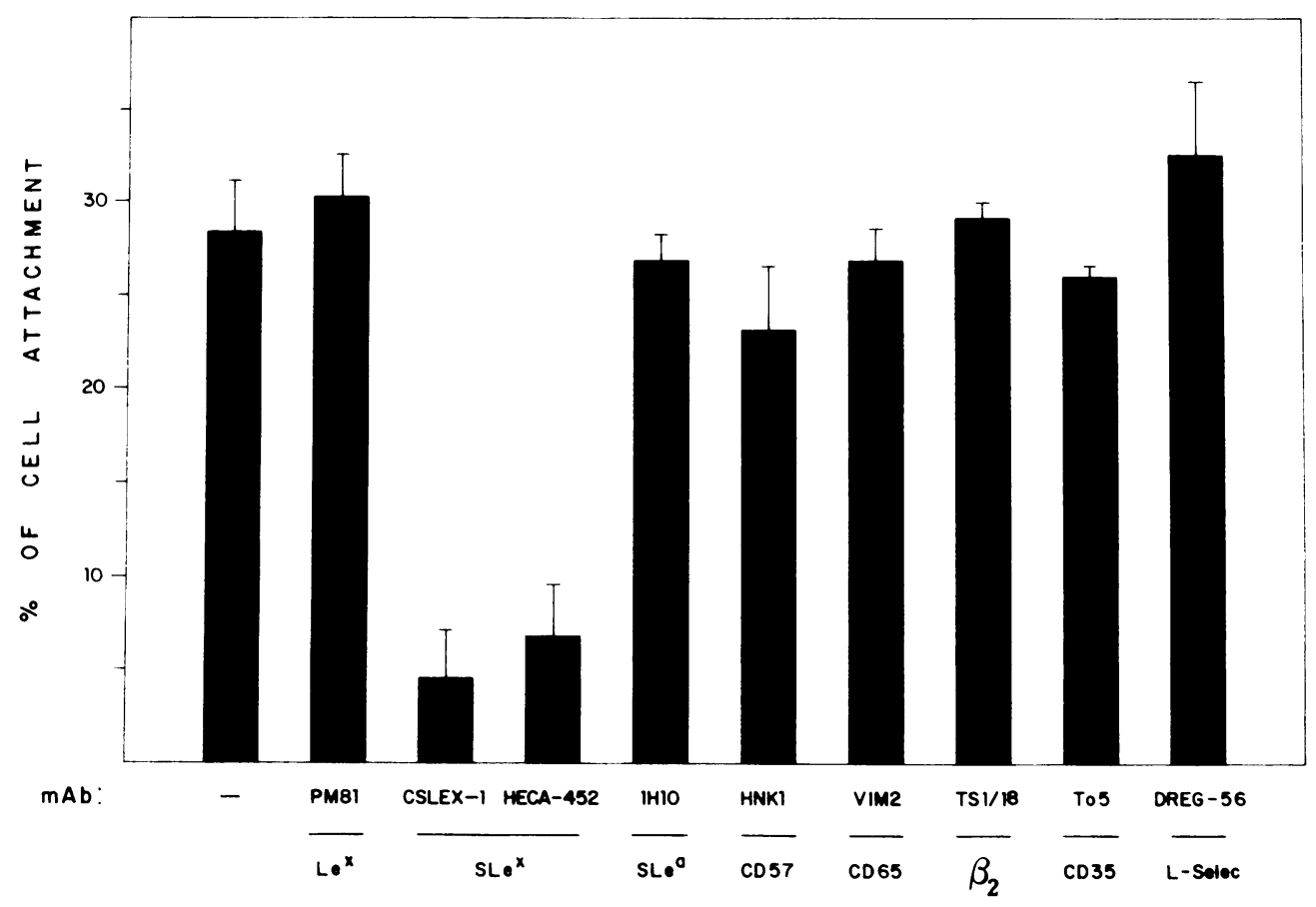

Figure 5. B cell binding to P-selectin in the presence of $\mathrm{mAbs}$ against different carbohydrate epitopes. B cells treated with PMA 5 $\mathrm{ng} / \mathrm{ml}$ for $2 \mathrm{~d}$ were incubated with $\mathrm{mAbs}$ against $\mathrm{P}$-selectin ( $\mathrm{Gl}$ $\mathrm{mAb})$. Le ${ }^{\times}$(G7C5 + PM81 mAb), sLe ( CSLEX-1 mAb). sLe '/CLA (HECA-452 mAb). CDw65 (VIM-2 mAb), CD57 (HNK-1 mAb). L-selectin (Dreg$56 \mathrm{mAb}$ ), CD35 (To5 mAb). $\beta 2$ integrin ( TS $1 / 18 \mathrm{mAb}$ ). Adhesion assays were performed as described in Methods. also inhibited by CSLEX-1 and HECA-452 mAbs (Fig. 5). Several Le ${ }^{x}$ Abs, and mAbs recognizing CDw65 and sLe carbohydrates did not inhibit the binding of activated B cells to purified P-selectin (Fig. 5). Although P-selectin also recognizes different sulfated carbohydrates as those recognized by the HNK-1 mAb, this mAb did not show any effect in B cell adhesion to P-selectin (Fig. 5).

Binding of B cells to both vascular selectins was unaffected by preincubation with anti-L-selectin DREG-56 mAb, even though this $\mathrm{mAb}$ inhibits neutrophil adhesion to $\mathrm{E}$ - and P-selectins $(21,22)$, (Figs. 4 and 5). Likewise, mAbs blocking Le ${ }^{\mathrm{x}}$ bearing proteins $\mathrm{CD} 35$ - and $\beta 2$ integrin-dependent interactions did not affect $\mathrm{B}$ cell binding to both vascular selectins (Figs. 4 and 5 ).

Treatment of activated $B$ cells with neuraminidase abolished cell binding to E- and P-selectins (data not shown). Thus, the sLe $^{x}$ and HECA-452 mAb-reactive protein(s) are the major components on activated $\mathrm{B}$ cells interacting with both vascular selectins.

Expression of fucosyltransferases during activation of $B$ lymphocytes. The expression of the different sialylated fucosylated lactosaminoglycans involved in selectin-mediated cell interactions depends on the action of different fucosyltransferases (FucT) (for review see references 9, 10, 53-58). Several FucT activities have been defined based on biochemical characteristics including their capacity to transfer fucose residues to sialylated saccharides or to type I or II acceptor chains (54). Recently, the search of the enzymatic activities responsible for $\alpha(1,3)$ and $\alpha(1,4)$ fucosylation has led to the identification of the primary structure of four FucTs (FucT-III to -VI) (14, 46$48,55-58)$.

We investigated whether any of these FucTs was induced during B cell activation by Northern blot analyses using specific probes for FucT-III to -VI (Fig. 6). Cellular FucT-III (Lewis
FucT) and -IV (myeloid FucT) were detected on epithelial A431 cells and myeloid U937 and HL60 cells, respectively, but not on activated B cells (Fig. 6, $A$ and $B$ ). On the other hand, we detected FucT-V and -VI transcripts on hepatoma HepG2 and epidermoid A431 cells but not on activated B cells (Fig. 6. $C$ and $D$ ).

These results show that any of the thus far cloned FucTs are expressed, or at least at significant levels, on B lymphocytes, thus suggesting that a new Fuc-T(s) would be responsible for the synthesis of these carbohydrate epitopes in B cells.

Crosslinking of the selectin-binding epitopes increased $B$ cell attachment to fibronectin and ICAM-1. Adhesion of circulating cells to the endothelium, ulterior extravasation and interaction with subendothelial extracellular matrix components (ECM) result from the sequential and cooperative participation of selectins and integrins (3-5). We sought whether B cell interaction with selectins could regulate further attachment to endothelium and ECM through $\beta 1$ and $\beta 2$ integrins. To this effect, we crosslinked the sLe ${ }^{x}$ and HECA-452 epitopes on two B cell lines, WIL2-NS and GUS, expressing most selectinbinding carbohydrates and studied their $\alpha 4$ - and $\alpha \mathrm{L} \beta 2$-integrinmediated interactions with a fibronectin fragment (FN38) and VCAM-1 as well as with a recombinant form of ICAM-1, respectively (Fig. 7 and not shown).

Incubation of WIL2-NS and GUS cells with CSLEX-I and HECA-452 mAbs, followed by specific anti-mouse or anti-rat IgM antibodies resulted in an increased cell binding to FN38 and VCAM-1 whereas no effect was observed with control matched isotype mAbs (Fig. 7 and data not shown). Cell adhesion to ICAM-1 was also significantly enhanced by crosslinking of these epitopes in WIL2-NS cells but not in the $\alpha \mathrm{L} \beta 2$-low expressing GUS cells. No change in the binding to type I collagen was observed ( data not shown ). Increased B cell attachment to FN38 and ICAM-1 was mediated through $\alpha 4$ and $\alpha \mathrm{L} \beta 2$ 

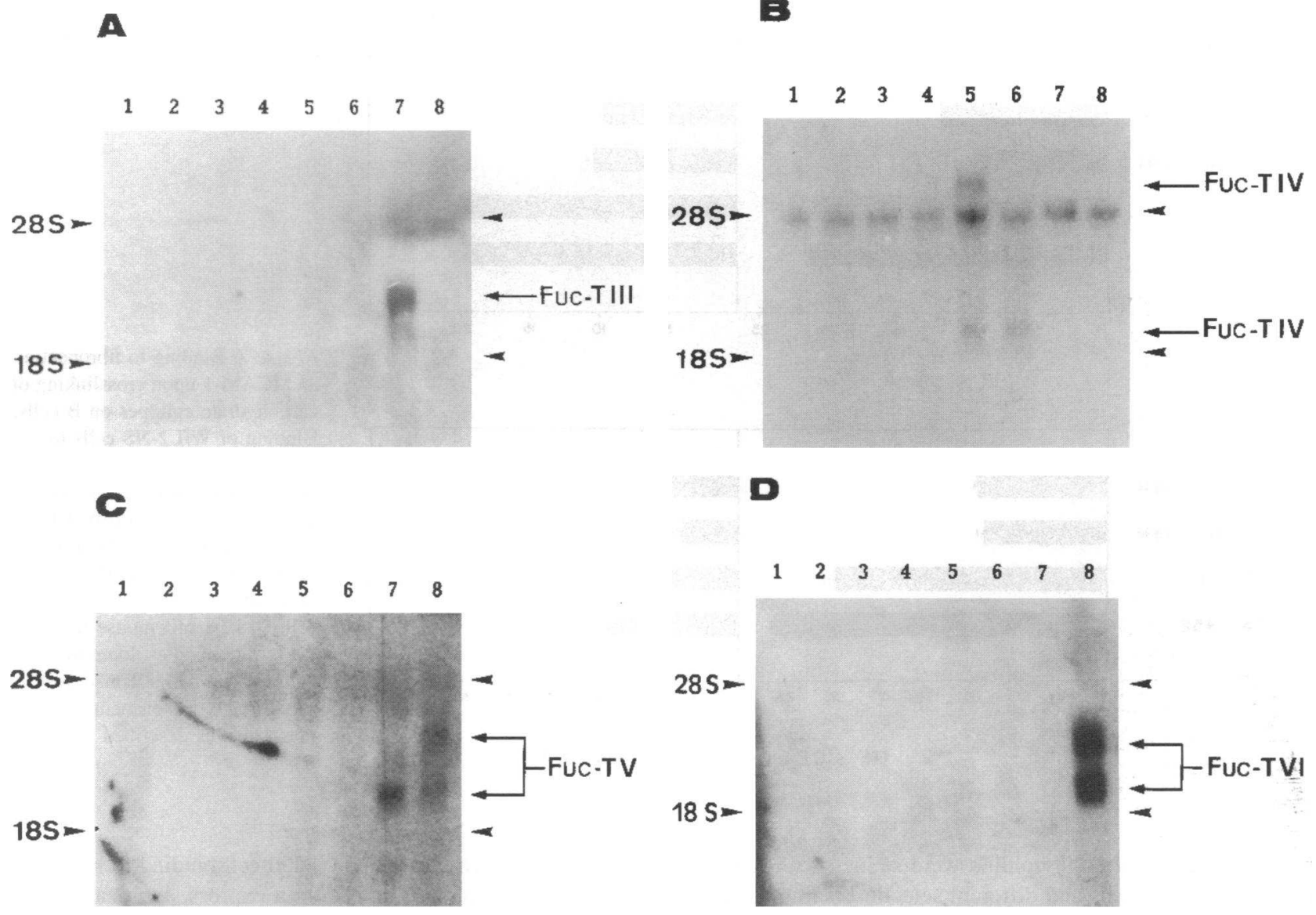

\section{$E$}
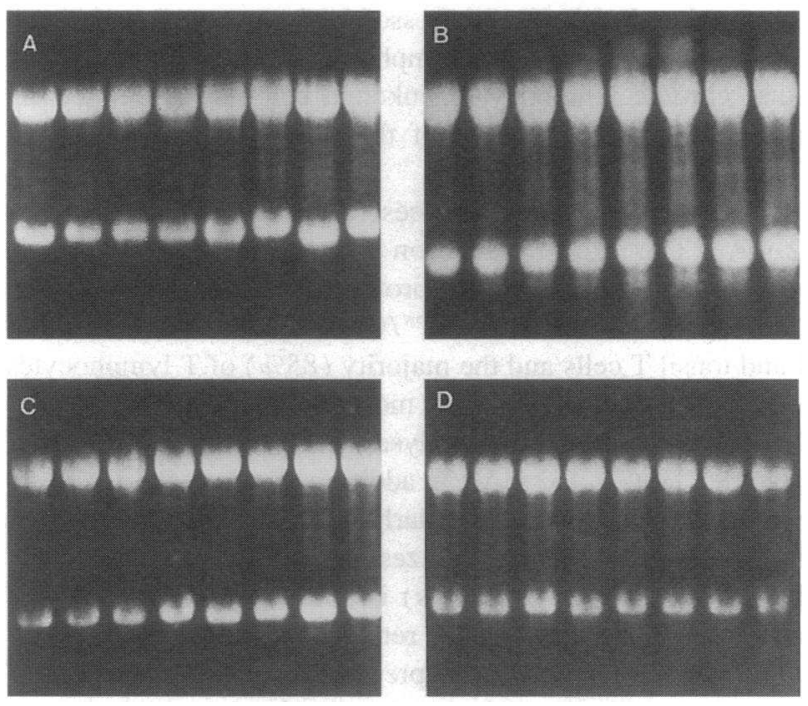

Figure 6. Expression of fucosyltransferases (FucT) III-VI on resting and activated B cells. Northern blots containing $30 \mu \mathrm{g}$ of total RNA from B cells either nonactivated (lane 1 ), or activated for 1,2 , or $3 \mathrm{~d}$ with $5 \mathrm{ng} /$ ml PMA (lanes 2, 3, and 4, respectively), HL60 cells (lane 5), U937 cells (lane 6), A431 cells (lane 7), and HepG2 cells (lane 8 ) were blotted with probes for FucT-III $(A),-$ IV $(B),-\mathrm{V}(C)$ and -VI $(D)$. RNA controls of the corresponding $(A-D)$ blots are included $(E)$.

The expression of selectin-binding epitopes on B cells infiltrating inflamed tissues parallels the expression of E-selectin on follicular dendritic cells. To elucidate whether the expression of these glycosylated epitopes and the binding to vascular selectins by in vitro activated $B$ cells, could be a mechanism regulating $B$ cell interactions in vivo, we examined the expression of these adhesion molecules in diseases where B cells have been shown to participate. Thus, thyroid tissue sections from three integrins, respectively, as concluded from the specific inhibitory effect exerted by anti- $\alpha 4$ and anti- $\beta 2$ mAbs (data not shown) (44). Moreover, enhanced binding to these ligands upon crosslinking of these glycosylated epitopes was not accompanied by changes in the expression of $\alpha 4, \alpha \mathrm{L}$ or $\beta 1$ integrins (data not shown ), reflecting that a conformational change in $\alpha 4$ and $\mathrm{L} \beta 2$ integrins is likely accounting for these increased binding capacities. 

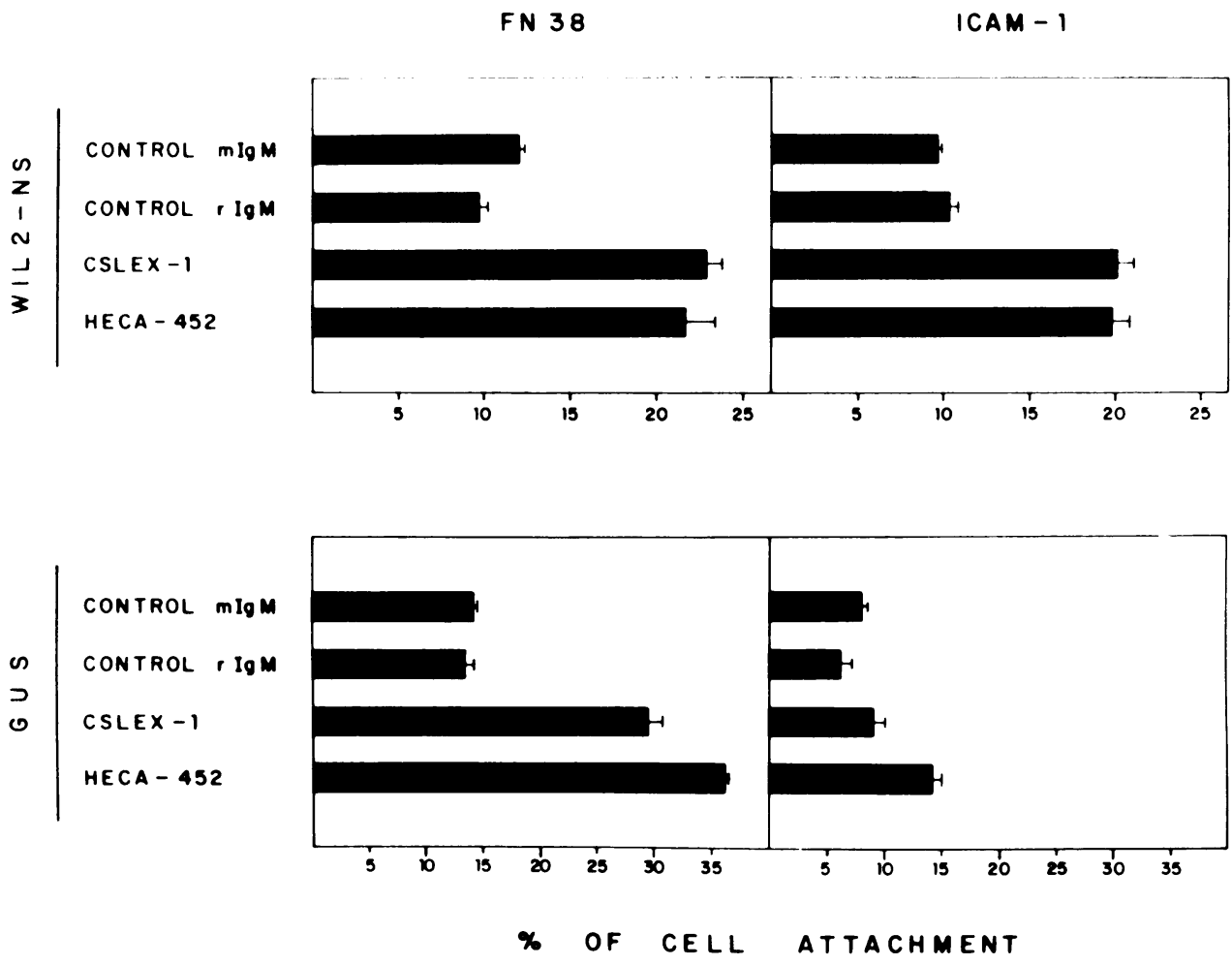

Figure 7. Binding to fibronectin and ICAM- 1 upon crosslinking of carbohydrate epitopes on $\mathrm{B}$ cells. Binding of WIL2-NS cells to FN38 fibronectin fragment and ICAM-I upon incubation with a control mouse IgM mAb ( $\mathrm{C} 6$ $\mathrm{mAb})$, a control rat IgM $\mathrm{mAb}$ (2B6), anti-sLe ${ }^{x}$ CSLEX-1 mAb and anti-Le'/CLA HECA mAb followed by anti-mouse and antirat IgM antibodies. Idem for GUS cells but with HNK 1 mAb instead of $\mathrm{C} 6 \mathrm{mAb}$. Experiments were performed as described in Methods.

patients with Hashimoto's thyroiditis were stained with mAbs against E- and P-selectins and different selectin-binding carbohydrates. In this process, infiltrating B cells organize in follicles mimicking the architecture of those found in normal lymphoid organs. In Hashimoto's thyroid sections we found expression of both selectins on EC (data not shown). Most interestingly, we detected a strong E-selectin staining in follicular germinal centers ( $\mathrm{GC}$ ) corresponding to the expression of this selectin by follicular dendritic cells (FDC) (Fig. $8 \mathrm{~A}$ ), as evidenced by parallel staining with the FDC-specific DRC-1 mAb (Fig. $8 B$ ) and by double staining with both mAbs (data not shown). A positive staining for $\mathrm{Le}^{\mathrm{x}}$, $\mathrm{sLe}^{\mathrm{x}}$, and HECA-452 epitopes was found in GC on both mononuclear cells and FDC (Fig. 8, $C-E$ ). The expression of these saccharides by $B$ cells was confirmed by parallel staining with the B cell-specific anti-CD20 B1 mAb (Fig. $8 F$ ), as well as by double staining for anti-HECA-452 (peroxidase) and anti-CD20 (alkaline phosphatase) mAbs (Fig. $8 \mathrm{G}$ ). Double staining for anti-DRC-1 and anti-HECA-452 $\mathrm{mAbs}$ demonstrated the expression of these saccharides also by FDC (Fig. $8 H$ ) (45).

\section{Discussion}

The results here reported demonstrate that $\mathrm{B}$ cell activation induces the expression of a number of carbohydrate determinants involved in B cell binding to $\mathrm{E}$ - and P-selectins. These glycosylated epitopes are also expressed on B cells infiltrating inflamed tissues such as in Hashimoto's thyroiditis and do not parallel with the induction of any of the so far cloned FucTs. Furthermore, the crosslinking of these determinants results in the upregulated function of $\beta 1$ and $\beta 2$ integrins probably reflecting conformational changes in these adhesion molecules.

Whereas other leukocytes constitutively express some of the glycosylated determinants involved in cell binding to E- and Pselectins, nonactivated $B$ cells do not express significant levels of any of them. However, B cell activation induces both the expression of most of these epitopes (Le ${ }^{x}$, sLe $^{x}$, CD57, and CDw65) and the capacity to interact with E- and P-selectins. Interestingly, $\mathrm{sLe}^{\mathrm{x}}$ is also expressed by immature $\mathrm{B}$ and $\mathrm{T}$ cell blasts in patients with acute lymphoblastic leukemia but not in mature chronic lymphocytic leukemia cells (59), delineating a precise expression pattern of these epitopes during B cell differentiation and activation.

$B$ cell activation also induces reactivity with the HECA$452 \mathrm{mAb}$. This $\mathrm{mAb}$, in addition to recognize sLe ${ }^{x}$ and $\mathrm{sLe}^{a}$, also reacts with a $200-\mathrm{kD}$ glycoprotein ( $\mathrm{s}$ ) known as CLA which is defining a small CSLEX-1 $1^{\text {to low }} / \mathrm{CD} 45 \mathrm{RO}^{\text {high }}$ subset $(15 \%)$ of PB and tonsil T cells and the majority ( $85 \%$ ) of T lymphocytes infiltrating chronic skin lesions ( most of the CD45RO ${ }^{\text {high }}$ phenotype ) $(24,52)$ Western blot analyses in activated B cells demonstrated that HECA-452 mAb, in addition to react with glycoproteins ranging $50-180 \mathrm{kD}$, similarly to those described in other cell types (45), also recognizes a protein(s) of $200 \mathrm{kD}$. Whether this $200-\mathrm{kD}$ protein $(\mathrm{s})$ is similar or identical to the thus far $\mathrm{T}$ cell-restricted CLA remains to be elucidated.

Despite the concomitant expression by activated B cells of all the selectin-binding epitopes described on myeloid-, T- and NK-cell adhesion to selectins, only CSLEX-1 and HECA-452 $\mathrm{mAbs}$ were able to inhibit $\mathrm{B}$ cell binding to $\mathrm{E}$ - and P-selectins. Although the inhibitory effect by these mAbs is almost complete, the existence of additional epitopes involved in these interactions can not be ruled out. To thas effect, bovine $\gamma / \delta \mathrm{T}$ cells, lacking $\mathrm{sLe}^{x}$ and CLA expression, are able to interact with E-selectin (36), suggesting the existence of new E-selectin-binding determinants in this T cell subset. In myeloid cells, $\mathrm{Le}^{\mathrm{x}}$ and $\mathrm{sLe}^{\mathrm{x}}$ epitopes are decorating different glycoproteins 

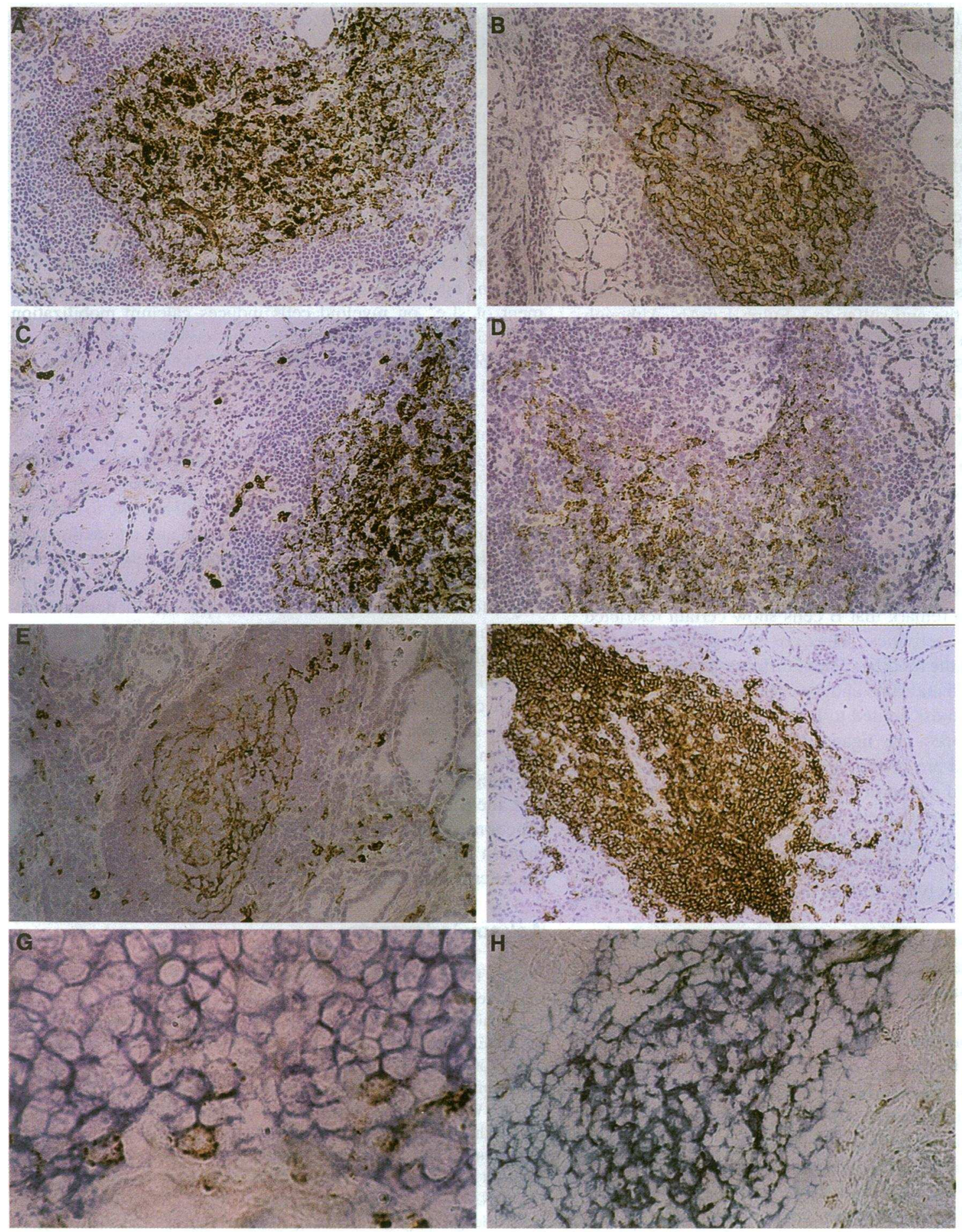

Figure 8. Immunostaining of thyroid sections from Hashimoto's patients for selectins and selectin-binding carbohydrate expression. Frozen tissue sections were single stained by immunoperoxidase technique with the following mAbs: anti-E-selectin TEA $3 / 9 \mathrm{mAb}(A)$; anti-DRC-1 mAb $(B)$; anti-Lex G7C5 mAb $(C)$; anti-sLex CSLEX-1 mAb $(D)$; and anti-CLA HECA-452 mAb $(E)$; and anti-CD20 B1 mAb $(F)$. Double immunostaining for HECA-452 mAb (peroxidase)/B1 mAb (alkaline phosphatase) $(G)$ and HECA-452 mAb (peroxidase)/anti-DRC-1 mAb (alkaline phosphatase) $(H)$. Magnifications were $\times 250(A-F), \times 1250(G)$, and $\times 500(H)$.

such as the L-selectin $(21,22), \beta 2$ integrins (50), CD35 (50), and the CEA-related CD66 antigen (23). Interestingly, during $B$ cell activation, parallely to the induction of $\operatorname{Le}^{x}$ and $S L e^{x}$, a severalfold increase in the expression of L-selectin, CD35 and $\alpha \mathrm{L} \beta 2$ integrin and the induction of $\alpha \mathrm{X} \beta 2$ integrin was ob- served. Although it has been described the involvement of CDw65 and $\mathrm{Le}^{\mathrm{x}}$ antigens in neutrophil binding to $\mathrm{E}-$ and $\mathrm{P}$ selectins, respectively $(26,27)$, we were unable to find any effect of these mAbs in agreement with other reports questioning the involvement of both epitopes in cell binding to 
vascular selectins $(15,56,57)$. As expected from the lack of effect of $\mathrm{Le}^{\mathrm{x}} \mathrm{mAbs}$ on $\mathrm{B}$ cell binding to $\mathrm{E}$ - and P-selectins, mAbs blocking CD35 and $\beta 2$ interactions had not inhibitory effect either. The failure of anti-L-selectin mAbs to block B cell interaction with $\mathrm{E}$ - and $\mathrm{P}$-selectins could be attributed to a differential processing of L-selectin in myeloid and B cells as previously reported for $\mathrm{T}$ cells (22).

Sulfatides and certain sulfated glycans are involved in myeloid and tumor cell binding to P-selectin $(29,30)$, but their mechanism of action is not yet clear $(20,30)$. Even though some sulfated saccharides partially inhibit B cell binding to Pselectin (A. A. Postigo, unpublished results), activated B cells do not react with the anti-sulfatide s Sulph I mAb. Although reactivity with this $\mathrm{mAb}$ has been strictly correlated with binding to P-selectin (29), other cell types binding to this selectin such as the neuroblastoma cell line NK-N-SH (60) as well as NK cells (37), lack reactivity for Sulph I mAb (A. A. Postigo, unpublished observations ).

The expression of the different sialylated fucosylated saccharides by activated B cells is not accompanied by the induction of FucT-III to -VI, suggesting that a new FucT(s) to be identified would be responsible of the synthesis of these epitopes in B cells. To this effect, studies from Lowe's group indicate the existence of new FucTs different to those heretofore cloned (57). It is worth to remark that B cells show certain restricted glycosyltransferase activities. Thus, $\alpha(2,6)$ sialyltransferase (ST) is involved in the modification of different proteins including CDw75, CDw76 and HB6 antigens $(61,62)$, some of them, like the CDw75, almost limited to B cells (61). Some of these $\alpha(2,6)$ sialic epitopes are ligands for the B cell-restricted $\mathrm{CD} 22 \beta$ antigen and are involved in cell-cell adhesions (62), although they would not participate in B cell adhesion to selectins since the addition of these residues prevent the action of $\alpha(1,3)$ FucTs and the generation of $\mathrm{sLe}^{\mathrm{x}}$. Thus, the generation of $\alpha(2,3)$ and $\alpha(2,6)$ residues would be competitive with each other since STs involved in their synthesis would use same substrates.

Albeit a very small fraction of B cells are usually present at sites of inflammation, a number of different processes, apart from B cell malignancies, involves tissue infiltration by B cells and could implicate their interaction with vascular selectins. Thus, B cells are present in the inflamed rheumatoid synovium and in Graves' and Hashimoto's thyroid diseases where vascular selectin expression has been reported $(49,63,64)$. In addition to E- and P-selectin expression by EC, we detected a strong expression of E-selectin on FDC. Interestingly, we also found the expression of different selectin-binding carbohydrates on follicular B cells. FDC have been involved in the conformation and organization of B cells into follicles as well as in the regulation of different $\mathrm{B}$ cell functions including the generation of memory B cells and Ig production (65). In the angiofollicular lymph node hyperplasia (Castleman's disease), a typical B cell disorder with abnormal GC organization and attributed to a chronic stimulation of B cells, an aberrant expression of Eselectin was detected on FDC and also on some giant cells contacting with B lymphocytes (66). Thus, it is tempting to speculate that in these and other processes, selectin-mediated adhesions could play a role in the interaction between B cells and FDC and interfering somehow B cell function. In that sense, the interaction of $\alpha 4 \beta 1$ and $\alpha \mathrm{L} \beta 2$ on B cells with VCAM-1 and ICAM-1 on FDC, respectively, has been suggested to be involved in several GC B cell functions and in the formation of the GC itself $(67,68)$.

Cell activation regulates not only the expression of the different adhesion molecules but also their ligand affinity $(1,2)$. Thus, it is largely reported that crosslinking of different cell surface glycoproteins upregulates integrin function by an still undefined conformational change $(s)(1,2)$. Our data demonstrate that crosslinking of these selectin-binding epitopes also increases B cell binding to FN38, VCAM-1, and ICAM-1 without changes in a 4 and $\alpha \mathrm{L} \beta 2$ integrin expression, reflecting a conformational change in these integrins probably secondary to signaling through these carbohydrates. In that sense, the engagement of $\mathrm{sLe}^{\mathrm{x}}$ on myeloid cells induces calcium mobilization and oxidative burst (69). Moreover, crosslinking of $\mathrm{Le}^{\mathrm{x}}$ on neutrophils also increases adhesion to ICAM- 1 although an increased expression of the $\mathrm{aL} \beta 2$ integrin is accounting for this effect (70). Recent models on leukocyte interaction with EC implicate selectins and integrins in subsequent and cooperative steps (3-7). Thus, from our data it could be hypothesized that adhesion of $\mathrm{sLe}^{\mathrm{x}}$-positive $\mathrm{B}$ cells to $\mathrm{E}$ - and P-selectins would trigger intracellular signaling enhancing cell binding to endothelial Ig members and posterior extravasation and interaction with ECM. In this regard, neutrophil adhesion to E-selectin enhances the avidity of $\alpha \mathrm{M} \beta 2$ integrin for C3bi (7). Although an inhibitory effect has been reported for neutrophil interactions with Pselectin (71), a recent work described an indirect stimulatory effect of P-selectin facilitating neutrophil interaction with endothelial PAF (72).

In conclusion, these results extend our knowledge about B cell adhesion mechanisms indicating an interplay between integrin- and selectin-mediated interactions. As already reported for integrins, the participation of these carbohydrates structures and their interaction with vascular selectins in other B cell functions such as B cell differentiation, proliferation or Ig production deserves further studies and open new perspectives in the interference of $B$ cell functions.

\section{Acknowledgments}

We are indebted to Drs. R. Lobb and R. P. McEver for the generous gift of recombinant E-selectin and purified $P$-selectin, respectively, that made this work possible. We also acknowledge the kind gift of mAbs by Drs E. D. Ball, E. L. Berg, E. C. Butcher, B. A. Fenderson, S. Goelz, T. K. Kishimoto, W. Knapp, R. Lobb, D. Y. Mason, R. P. McEver, P. Fredman, J. M. Rojo, K. M. Skubitz, P. I. Terasaki, J. S. Thompson, and H. Waldmann; the fibronectin fragment FN38 by Dr. A. GarcíaPardo; the recombinant soluble VCAM-1 by Dr. R. Lobb; and the recombinant ICAM-1 by Drs. H. Hedman and E. Lundgren. We also want to thank Drs. Bowen, Goelz, Koszdin, and Lowe for provide us with the cDNA probes for fucosyltransferases III, IV, V and VI. We greatly acknowledge insightful advice in immunohistochemical studies by Dr. F. Mampaso. We also appreciate the critical reading of the manuscript by Dr. A. L. Corbi.

This work was supported by grants from PB92-0738 (to M. O. de Landázuri), and Comunidad de Madrid (No. 280/92 to F. SánchezMadrid). A. A. Postigo is supported by a fellowship from INSALUD (FIS-BAE No. 93/5150).

Note added in proof. During the review of this manuscript two different groups characterized and cloned the Fuc-TVII (Sasaki, K., K. Kurata, K. Funayama, N. Nagata, E. Watanabe, S. Ohta, N. Harai, and T. Nishi. 1994. J. Biol. Chem. 269:14730-14737; Natsuka, S., K. M. Gersten, K. Zenita, R. Kannagi, and J. B. Lowe. 1994. J. Biol. Chem. 269:1678916794) which is also involved in the generation of the $\mathrm{sLe}^{\mathrm{x}}$ epitope. 
Sasaki et al. also showed that the transfection of the B cell line Namalwa with the cDNA encoding for Fuc-TVII induces the expression of $s L e^{x}$ and the corresponding binding to E-selectin indicating the existence of glycoproteins susceptible of $\alpha(1,3)$ fucosylation by Fuc-TVII on this B cell line.

\section{References}

1. Springer, T. A. 1990. Adhesion receptors of the immune system. Nature (Lond.). 346:425-434

2. Hynes, R. O. 1992. Integrins: versatility, modulation, and signaling in cell adhesion. Cell. 69:11-25.

3. Butcher, E. C. 1991. Leukocyte-endothelial cell recognition: three (or more) steps to specificity and diversity. Cell. 67:1033-1036.

4. Shimizu, Y., W. Newman, Y. Tanaka, and S. Shaw. 1992. Lymphocyte interactions with endothelial cells. Immunol. Today. 13:106-112.

5. McEver, R. P. 1992. Leukocyte-endothelial cell interactions. Curr. Opin. Cell Biol. 4:840-849.

6. Lawrence, M. B., and T. A. Springer. 1991. Leukocytes roll on a selectin at physiologic flow rates: distinction from and prerequisite for adhesion through integrins. Cell. 65:859-873.

7. Lo, S. K., S. Lee, R. A. Ramos, R. Lobb, M. Rosa, G. Chi-Rosso, and S. D. Wright. 1991. Endothelial-leukocyte adhesion molecule 1 stimulates the adhesive activity of leukocyte integrin CR3 (CD11b/CD18, Mac-1, $\alpha \mathrm{m} \beta 2)$ on human neutrophils. J. Exp. Med. 173:1493-1500.

8. Bevilacqua, M. P., and R. M. Nelson. 1993. Selectins. J. Clin. Invest. 91:379-387.

9. Kuijpers, T. W. 1993. Terminal glycosyltransferase activity: a selective role in cell adhesion. Blood. 81:873-881.

10. Feizi, T. 1993. Oligosaccharides that mediate mammalian cell-cell adhesion. Curr. Opin. Struct. Biol. 3:701-710.

11. Phillips, M. L., E. Nudelman, F. C. A. Gaeta, M. Perez, A. K. Singhal, S. I. Hakomori, and J. C. Paulson. 1990. ELAM-1 mediates cell adhesion by recognition of a carbohydrate ligand, sialyl-Le ${ }^{\mathrm{x}}$. Science (Wash. DC). 250:11301132.

12. Walz, G., A. Aruffo, W. Kolanus, M. Bevilacqua, and B. Seed. 1990. Recognition by ELAM-1 of the sialyl-Le ${ }^{\mathrm{x}}$ determinant on myeloid and tumor cells. Science (Wash. DC). 250:1132-1135

13. Lowe, J. B., L. M. Stoolman, R. P. Nair, R. D. Larsen, T. L. Berhend, and R. M. Marks. 1990. ELAM-1-dependent cell adhesion to vascular endothelium determined by a transfected human fucosyltransferase cDNA. Cell. 63:475-484.

14. Goelz, S., E., C. Hession, D. Goff, B. Griffiths, R. Tizard, B. Newman, G. Chi-Rosso, and R. Lobb. 1990. ELFT: A gene that directs the expression of an ELAM-1 ligand. Cell. 63:1349-1356.

15. Polley, M. J., M. L. Phillips, E. Wayner, E. Nudelman, A. K. Singhal, S.-I. Hakomori, and J. C. Paulson. 1991. CD62 and endothelial cell-leukocyte adhesion molecule 1 (ELAM-1) recognize the same carbohydrate ligand, sialyl-Lewis $\mathbf{x}$. Proc. Natl. Acad. Sci. USA. 88:6224-6228.

16. Berg, E. L., M. K. Robinson, O. Mansson, E. C. Butcher, and J. L. Magnani, 1991. A carbohydrate domain common to both sialyl $\mathrm{Le}^{\mathrm{a}}$ and sialyl $\mathrm{Le}^{\mathrm{x}}$ is recognized by the endothelial cell leukocyte adhesion molecule ELAM-1. J. Biol. Chem. 266:14869-14872.

17. Foxall, C., S. R. Watson, D. Dowbenko, C. Fennie, L. A. Lasky, M. Kiso, A. Hasegawa, D. Asa, and B. K. Brandley. 1992. The three members of the selectin receptor family recognize a common carbohydrate epitope, the sialyl Lewis x oligosaccharide. J. Cell Biol. 117:895-902.

18. Berg, E. L., J. Magnani, R. A. Warnock, M. K. Robinson, and E. C. Butcher. 1992. Comparison of L-selectin and E-selectin ligand specifities: the Lselectin can bind the E-selectin ligands sialyl Le ${ }^{\mathrm{x}}$ and sialyl Le ${ }^{\mathrm{a}}$. Biochem. Biophys. Res. Commun. 184:1048-1052.

19. Zhou, Q., K. L. More, D. F. Smith, A. Varki, R. P. McEver, and R. D. Cummings. 1991. The selectin GMP-140 binds to sialylated, fucosylated lactosaminoglycans on both myeloid and nonmyeloid cells. J. Cell Biol. 115:557-564.

20. Handa, K., E. D. Nudelman, M. R. Stroud, T. Shiozawa, and S.-I. Hakomori. 1993. Selectin GMP-140 (CD62, PADGEM) binds to sialosyl-Le a and sialosyl-Le ${ }^{\times}$and sulfated glycans modulate this binding. Biochem. Biophys. Res. Commun. 181:1223-1230.

21. Picker, L. J., R. A. Warnock, A. R. Burns, C. M. Doerschuk, E. L. Berg, and E. C. Butcher. 1991. The neutrophil selectin LECAM-1 presents carbohydrate ligands to the vascular selectins ELAM-1 and GMP-140. Cell. 66:921-933.

22. Kishimoto, T. K., R. A. Warnock, R. A. Jutila, E. C. Butcher, C. Lane, and D. C. Anderson. 1991. Antibodies against human neutrophil LECAM-1 (LAM-1, Leu-8, DREG-56 antigen ) and endothelial cell ELAM-1 inhibit a common CD18independent adhesion pathways in vitro. Blood. 78:805-811.

23. Kuijpers, T. W., M. Hoogerwerf, L. J. W. van der Laan, G. Nagel, C. E. van der Schoot, F. Grunert, and D. Roos. 1992. CD66 nonspecific cross-reacting antigens are involved in neutrophil adherence to cytokine-activated endothelial cells. J. Cell Biol. 118:457-466.
24. Berg, E. L., T. Yoshino, L. S. Rott, M. K. Robinson, A. Warnock, T. K. Kishimoto, L. J. Picker, and E. C. Butcher. 1991. The cutaneous lymphocyte antigen is a skin lymphocyte homing receptor for the vascular lectin endothelial cell-leukocyte adhesion molecule 1. J. Exp. Med. 174:1461-1466.

25. Rossiter, H., F. van Reijsen, G. C. Mudde, F. K. Kalthoff, C. A. F. M. Bruijnzeel-Koomen, L. J. Picker, and T. S. Kupper. 1994. Skin disease-related T cells bind to endothelial selectins: expression of cutaneous lymphocyte antigen (CLA) predicts E-selectin but not P-selectin binding. Eur. J. Immunol. 24:205210.

26. Tiemeyer, M., S. J. Swiedler, M. Ishihara, M. Moreland, H. Schweingruber, P. Hirtzer, and B. K. Brandley. 1991. Carbohydrate ligands for endothelialleukocyte adhesion molecule-1. Proc. Natl. Acad. Sci. USA. 88:1138-1142.

27. Tyrell, D., P. James, N. Rao, C. Foxall, S. Abbas, F. Dasgupta, M. Nashed, A. Hasegawa, M. Kiso, D. Asa, J. Kidd, and B. K. Brandley. 1991. Structural requirements for the carbohydrate ligand of E-selectin. Proc. Natl. Acad. Sci. USA. 88:10372-10376.

28. Larsen, E., T. Palabrica, S. Sajer, G. E. Gilbert, D. D. Wagner, B. C. Furie and B. Furie. 1990. PADGEM-dependent adhesion of platelets to monocytes and neutrophils is mediated by a lineage-specific carbohydrate, LNF III (CD15). Cell. 63:467-474.

29. Aruffo, A., W. Kolanus, G. Walz, P. Fredman, and B. Seed. 1991. CD62/ P-selectin recognition of myeloid and tumor cell sulfatides. Cell. 67:35-44.

30. Skinner, M. P., C. M. Lucas, G. F. Burns, C. N. Chesterman, and M. C. Berndt. 1991. GMP-140 binding to neutrophils is inhibited by sulfated glycans. J. Biol. Chem. 266:5371-5374.

31. Pinola, M., R. Renkonen, M.-L. Majuri, S. Tiisala, and E. Saksela. 1994. Characterization of the E-selectin ligand on NK cells. J. Immunol. 152:35863594.

32. Graber, N., T. V. Gopal, D. Wilson, L. D. Beall, T. Polte, and W. Newman. 1990. T cells bind to cytokine-activated endothelial cells via a novel inducible sialoglycoprotein and ELAM-1. J. Immunol. 145:819-830.

33. Picker, L., J., T. K. Kishimoto, C. W. Smith, R. A. Warnock, and E. C. Butcher. 1991. ELAM-1 is an adhesion molecule for skin-homing T cells. Nature (Lond.). 349:796-799.

34. Shimizu, Y., S. Shaw, N. Graber, T. Venkat Gopal, K. J. Horgan, G. A. van Seventer, and W. Newman. 1991. Activation-independent binding of human memory T cells to adhesion molecule ELAM-1. Nature (Lond.). 349:799-802.

35. Moore, K. L., A. Varki, and R. P. McEver. 1991. GMP-140 binds to a glycoprotein receptor on human neutrophils: evidence for a lectin-like interaction. J. Cell Biol. 112:491-499.

36. Walcheck, B., G. Watts, and M. A. Jutila. 1993. Bovine $\gamma / \delta$ T cells bind E-selectin via a novel glycoprotein receptor: first characterization of a lymphocyte/ E-selectin interaction in an animal model. J. Exp. Med. 178:853-863.

37. Moore, K. L., and L. F. Thompson. 1992. P-selectin (CD62) binds to subpopulations of human memory $\mathrm{T}$ lymphocytes and natural killer cells. Biochem. Biophys. Res. Commun. 186:173-181.

38. Damle, N. K., K. Klussman, M. T. Dietsch, N. Mohagheghpour, and A. Aruffo. 1992. GMP-140 (P-selectin/CD62) binds to chronically stimulated but not resting CD4 + $\mathrm{T}$ lymphocytes and regulates their production of proinflammatory cytokines. Eur. J. Immunol. 22:1789-1793.

39. Postigo, A. A., R. Garcia-Vicuña, F. Diaz-Gonzalez, A. G. Arroyo, M. O. de Landázuri, G. Chi-Rosso, R. R. Lobb, A. Laffón, and F. SánchezMadrid. 1992. Increased binding of synovial T lymphocytes from rheumatoid arthritis to endothelial-leukocyte adhesion molecule-1 (ELAM-1) and vascular cell adhesion molecule-1 (VCAM-1). J. Clin. Invest. 89:1445-1452.

40. Stevens, S. K., I. L. Weissman, and E. C. Butcher. 1982. Differences in the migration of $\mathrm{T}$ and $\mathrm{B}$ lymphocytes: organ selectivity and the role of lymphoid endothelial cell recognition. J. Immunol. 128:844-852.

41. Postigo, A. A., R. Pulido, M. R. Campanero, A. Acevedo, A. GarcíaPardo, A. L. Corbi, F. Sánchez-Madrid, and M. O. de Landázuri. 1991. Differential expression of VLA-4 integrin by resident and peripheral blood B lymphocytes. Acquisition of functionally active $\alpha 4 \beta 1$ fibronectin receptors upon B cell activation. Eur. J. Immunol. 21:2437-2445.

42. Postigo, A. A., A. L. Corbi, F. Sánchez-Madrid, and M. O. de Landázuri. 1991. Regulated expression and function of CD11c/CD18 integrin on human B lymphocytes. Relation between attachment to fibrinogen and triggering of proliferation through CD11c/CD18. J. Exp. Med. 174:1313-1322.

43. Thoma, S., J. E. Ramberg, and P. E. Lipsky. 1992. Expression and distribution of CD11a/CD18 and CD54 during human T cell-B cell interactions. $J$. Leukocyte Biol. 52:97-103.

44. Postigo, A. A., P. Sánchez-Mateos, A. I. Lazarovits, F. Sánchez-Madrid, and M. O. de Landázuri. 1993. $\alpha 4 \beta 7$ integrin mediates B cell binding to fibronectin and Vascular Cell Adhesion Molecule-1. Expression and function of $\alpha 4$ integrins on human B lymphocytes. J. Immunol. 151:2471-2483.

45. Picker, L. J., S. A. Michie, L. S. Rott, and E. C. Butcher. 1990. A unique phenotype of skin-associated lymphocytes in human. Preferential expression of the HECA-452 epitope by benign and malignant T cells at cutaneous sites. Am. J. Pathol. 136:1053-1068.

46. Kukowska-Latallo, J., R. D. Larsen, R. P. Nair, and J. B. Lowe. 1990. A cloned human cDNA determines expression of a mouse stage-specific embryonic 
antigen and the Lewis blood group $\alpha(1,3 / 1,4)$ fucosyltransferase. Genes \& Dev. 4:1288-1303.

47. Weston, B. W., R. P. Nair, R. D. Larsen, and J. B. Lowe. 1992. Isolation of a novel human $\alpha(1,3)$ fucosyltransferase gene and molecular comparison to the human Lewis blood group $\alpha(1,3 / 1,4)$ fucosyltransferase gene. Syntenic homologous, nonallelic genes encoding enzymes with distinct acceptor substrate specifities. J. Biol. Chem. 267:4152-4160.

48. Koszdin, K. L., and B. R. Bowen. 1992. The cloning and expression of a human $\alpha-1,3$ fucosyltransferase capable of forming the E-selectin ligand. Biochem. Biophys. Res. Commun. 187:152-157.

49. Munro, J. M., S. K. Lo, C. Corless, M. J. Robertson, N. C. Lee, R. L. Barnhill, D. S. Weinberg, and M. P. Bevilacqua. 1992. Expression of sialyl-Lewis $\mathrm{X}$, an E-selectin ligand, in inflammation, immune processes and lymphoid tissues. Am. J. Pathol. 141:1397-1408.

50. Skubitz, K. M., and R. W. Snook II. 1987. Monoclonal antibodies that recognize lacto- $\mathrm{N}$-fucopentaose III (CD15) react with the adhesion-promoting glycoprotein family (LFA-1/HMAC-1/GP 150,95) and CR1 on human neutrophils. J. Immunol. 139:1631-1639.

51. Needham, L. K., and R. L. Schnaar. 1993. The HNK-1 reactive sulfoglucuronyl glycolipids are ligands for L-selectin and P-selectin but not E-selectin. Proc. Natl. Acad. Sci. USA. 90:1359-1363.

52. Picker, L. J., J. R. Treer, B. Ferguson-Darnell, P. A. Collins, P. R. Bergstresser, and L. W. M. M. Terstappen. 1993. Control of lymphocyte recirculation in man. II. Differential regulation of the cutaneous lymphocyte-associated antigen, a tissue-selective homing for skin-homing T cells. J. Immunol. 150:1122-1136.

53. van den Eijnden, D. H., and D. H. Joziasse. 1993. Enzymes associated with glycosylation. Curr. Opin. Struct. Biol. 3:711-721.

54. Mollicone, R., J. J. Candelier, B. Mennesson, P. Couillin, A. P. Venot, and R. Oriol. 1992. Five specifity patterns of (1-3)- $\alpha$-L-fucosyltransferase activity defined by use of synthetic oligosaccharide acceptors. Differential expression of the enzymes during human embryonic development and in adult tissues. Carbohydr. Res. 28:265-276.

55. Kumar, R., B. Potvin, W. A. Muller, and P. Stanley. 1991. Cloning of a human a $(1,3)$ fucosyltransferase gene that encodes ELFT but does not confer ELAM-1 recognition on chinese hamster ovary cell transfectants. J. Biol. Chem. 266:21777-21783.

56. Lowe, J. B., J. F. Kukowska-Latallo, R. P. Nair, R. D. Larsen, R. M. Marks, B. A. Macher, R. J. Kelly, and L. K. Ernst. 1991. Molecular cloning of a human fucosyltransferase that determines expression of the Lewis $\mathrm{x}$ and VIM2 epitopes but not ELAM-1-dependent cell adhesion. J. Biol. Chem. 266:1746717477.

57. Weston, B. W. P. L. Smith, R. J. Kelly, and J. B. Lowe. 1992. Molecular cloning of a fourth member of a human $a(1,3)$ fucosyltransferase gene family. Multiple homologous sequences that determine expression of the Lewis $x$, sialyl Lewis X, and difucosyl sialyl Lewis x epitopes. J. Biol. Chem. 267:24575-24584.

58. Goelz, S., R. Kumar, B. Potvin, S. Sundaram, M. Brickelmaier, and P. Stanley. 1994. Differential expression of an E-selectin ligand (sLex) by two chinese hamster ovary cell lines transfected with the same a $(1,3)$-fucosyltransferase gene (ELTF). J. Biol. Chem. 269:1033-1040.

59. Ohmori, K., T. Yoneda, G. Ishihara, K. Shigeta, K. Hirashima, M. Kanai,
S. Itai, T. Sasaoki, S. Arii, H. Arita, and R. Kannagi. 1989. Sialyl SSEA-1 antigen as a carbohydrate marker of human natural killer cells and immature lymphoid cells. Blood. 74:255-261.

60. Stone, J. P., and D. D. Wagner. 1993. P-selectin mediates adhesion of platelets to neuroblastoma and small cell lung cancer. J. Clin. Invest. 92:804813.

61. Bast, B. J. E. G., L-J. Zhou, G. J. Freeman, K. J. Colley, T. J. Ernst, J. M. Munro, and T. Tedder. 1992. The HB-6, CDw75, and CD76 differentiation antigens are unique cell-surface carbohydrate determinants generated by the $\beta$ galactoside a2,6-sialyltransferase. J. Cell Biol. 116:423-435.

62. Sgroi, D., A. Varki, S. Braesch-Andersen, and I. Stamenkovic. 1993 CD22, a B cell specific immunoglobulin superfamily member, is a sialic acid binding lectin. J. Biol. Chem. 268:7011-7018.

63. Miyazaki, A., T. Mirakian, and G. F. Bottazzo. 1992. Adhesion molecule expression in Grave's thyroid glands; potential relevance of granule membrane protein (GMP-140) and intercellular adhesion molecule-1 (ICAM-1) in the homing and antigen presentation processes. Clin. Exp. Immunol. 89:52-57.

64. Cotran, R. S., M. A. Gimbrone, M. P. Bevilacqua, D. L. Mendrick, and J. S. Pober. 1986. Induction and detection of a human endothelial activation antigen in vivo. J. Exp. Med. 164:661-666.

65. Klaus, G. G. B., J. H. Humphrey, A. Kunkl, and D. W. Dongworth. 1980 The follicular dendritic cell: its role in antigen presentation in the generation of immunological memory. Immunol. Rev. 53:3-28.

66. Ruco, L. P., A. J. H. Gearing, R. Pigott, D. Pomponi, V. L. Burgio, A Cafolla, A. Baiocchini, and C. D. Baroni. 1991. Expression of ICAM-1, VCAM1 and ELAM-1 in angiofollicular lymph node hyperplasia (Castleman's disease) evidence for dysplasia of follicular dendritic reticulum cells. Histopathology (Oxf.). 19:523-528.

67. Freedman, A. S., J. M. Munro, G. E. Rice, M. P. Bevilacqua, C. Morimoto, B. W. McIntyre, K. Rhynhart, J. S. Pober, and L. M. Nadler. 1990. Adhesion of human B cells to germinal centers in vitro involves VLA-4 and INCAM-110. Science (Wash. DC). 249:1030-1033.

68. Koopman, G., H. K. Parmentier, H-K. Schuurman, W. Newman, C. J. L. M. Meijer, and S. Pals. 1991. Adhesion of human B cells to follicular dendritic cells involves both the lymphocyte function-associated antigen1/intercellular adhesion molecule 1 and very late antigen 4/vascular cell adhesion molecule 1 pathways. J. Exp. Med. 173:1297-1304.

69. Lund-Johansen, F., J. Olweus, V. Horejsi, K. M. Skubitz, J. S. Thompson, R. Vilella, and F. W. Symington. 1992. Activation of human phagocytes through carbohydrate antigens (CD15, sialyl-CD15, CDw17, and CDw65). J. Immunol. $148: 3221-3229$

70. Forsyth, K. D., A. C. Simpson, and R. J. Levinsky. 1989. CD15 antibodies increase neutrophil adhesion to endothelium by an LFA-1-dependent mechanism Eur. J. Immunol. 19:1331-1334.

71. Wong, C. S., J. R. Gamble, M. P. Skinner, C. M. Lucas, M. C. Berndt and M. A. Vadas. 1991. Adhesion protein GMP140 inhibits superoxide anion release by human neutrophils. Proc. Natl. Acad. Sci. USA. 88:2397-2401.

72. Lorant, D. E., M. K. Topham, R. E. Whatley, R. P. McEver, T. M. McIntyre, S. M. Prescott, and G. A. Zimmerman. 1993. Inflammatory roles of Pselectin. J. Clin. Invest. 92:559-570. 